\title{
Chemical and aerosol characterisation of the troposphere over West Africa during the monsoon period as part of AMMA
}

\author{
C. E. Reeves ${ }^{1}$, P. Formenti ${ }^{2}$, C. Afif ${ }^{2,3}$, G. Ancellet ${ }^{4}$, J.-L. Attie ${ }^{5,6}$, J. Bechara ${ }^{2}$, A. Borbon ${ }^{2}$, F. Cairo ${ }^{7}$, H. Coe $^{8}$, \\ S. Crumeyrolle ${ }^{6,9}$, F. Fierli ${ }^{7}$, C. Flamant ${ }^{7}$, L. Gomes ${ }^{6}$, T. Hamburger ${ }^{10}$, C. Jambert ${ }^{5}$, K. S. Law ${ }^{4}$, C. Mari ${ }^{5}$, \\ R. L. Jones ${ }^{11}$, A. Matsuki ${ }^{9,12}$, M. I. Mead ${ }^{11}$, J. Methven ${ }^{13}$, G. P. Mills ${ }^{1}$, A. Minikin ${ }^{10}$, J. G. Murphy ${ }^{1, *}$, J. K. Nielsen ${ }^{14}$, \\ D. E. Oram ${ }^{1}$, D. J. Parker ${ }^{15}$, A. Richter ${ }^{16}$, H. Schlager ${ }^{10}$, A. Schwarzenboeck ${ }^{9}$, and V. Thouret ${ }^{5}$ \\ ${ }^{1}$ School of Environmental Sciences, University of East Anglia, Norwich, UK \\ ${ }^{2}$ LISA, UMR CNRS 7583, Université Paris Est Créteil et Université Paris Diderot, Institut Pierre Simon Laplace, \\ Créteil, France \\ ${ }^{3}$ Department fo Chemistry, Faculty of Sciences, Saint Joseph University, Beirut, Lebanon \\ ${ }^{4}$ LATMOS, Université Paris VI, Université Versailles-St-Quentin, CNRS, Paris, France \\ ${ }^{5}$ Laboratoire d'Aérologie, Université de Toulouse, CNRS, UMR, Toulouse, France \\ ${ }^{6}$ Centre National de Recherches Meteorologiques, Meteo-France, Toulouse, France \\ ${ }^{7}$ Istituto di Scienze dell' Atmosfera e del Clima, Consiglio Nazionale delle Ricerche, Italy \\ ${ }^{8}$ School of Earth, Atmospheric \& Environmental Sciences, University of Manchester, Manchester, UK \\ ${ }^{9}$ Laboratoire de Météorologie Physique, Université Blaise Pascal, Clermont-Ferrand, France \\ ${ }^{10}$ Deutsches Zentrum für Luft- und Raumfahrt (DLR), Institut für Physik der Atmosphäre, \\ Oberpfaffenhofen Wessling, Germany \\ ${ }^{11}$ Department of Chemistry, Univeristy of Cambridge, Cambridge, UK \\ ${ }^{12}$ Frontier Science Organization, Kanazawa University, Japan \\ ${ }^{13}$ Department of Meteorlogy, University of Reading, Reading, UK \\ ${ }^{14}$ Danish Meteorological Institute, Research and Development Division, Copenhagen, Denmark \\ ${ }^{15}$ School of Earth and Environment, University of Leeds, Leeds, UK \\ ${ }^{16}$ Institute of Environmental Physics, University of Bremen, Bremen, Germany \\ * now at: Department of Chemistry, University of Toronto, Toronto, Canada
}

Received: 14 January 2010 - Published in Atmos. Chem. Phys. Discuss.: 16 March 2010

Revised: 20 July 2010 - Accepted: 26 July 2010 - Published: 16 August 2010

\begin{abstract}
During June, July and August 2006 five aircraft took part in a campaign over West Africa to observe the aerosol content and chemical composition of the troposphere and lower stratosphere as part of the African Monsoon Multidisciplinary Analysis (AMMA) project. These are the first such measurements in this region during the monsoon period. In addition to providing an overview of the tropospheric composition, this paper provides a description of the measurement strategy (flights performed, instrumental payloads, wing-tip to wing-tip comparisons) and points to some of the important findings discussed in more detail in other papers in this special issue.
\end{abstract}

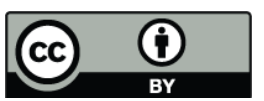

Correspondence to: C. E. Reeves (c.reeves@uea.ac.uk)
The ozone data exhibits an "S" shaped vertical profile which appears to result from significant losses in the lower troposphere due to rapid deposition to forested areas and photochemical destruction in the moist monsoon air, and convective uplift of ozone-poor air to the upper troposphere. This profile is disturbed, particularly in the south of the region, by the intrusions in the lower and middle troposphere of air from the southern hemisphere impacted by biomass burning. Comparisons with longer term data sets suggest the impact of these intrusions on West Africa in 2006 was greater than in other recent wet seasons. There is evidence for net photochemical production of ozone in these biomass burning plumes as well as in urban plumes, in particular that from Lagos, convective outflow in the upper troposphere and in boundary layer air affected by nitrogen oxide emissions from recently wetted soils. This latter effect, along with enhanced

Published by Copernicus Publications on behalf of the European Geosciences Union. 
deposition to the forested areas, contributes to a latitudinal gradient of ozone in the lower troposphere. Biogenic volatile organic compounds are also important in defining the composition both for the boundary layer and upper tropospheric convective outflow.

Mineral dust was found to be the most abundant and ubiquitous aerosol type in the atmosphere over Western Africa. Data collected within AMMA indicate that injection of dust to altitudes favourable for long-range transport (i.e. in the upper Sahelian planetary boundary layer) can occur behind the leading edge of mesoscale convective system (MCS) cold-pools. Research within AMMA also provides the first estimates of secondary organic aerosols across the West African Sahel and have shown that organic mass loadings vary between 0 and $2 \mu \mathrm{g} \mathrm{m}^{-3}$ with a median concentration of $1.07 \mathrm{\mu g} \mathrm{m}^{-3}$. The vertical distribution of nucleation mode particle concentrations reveals that significant and fairly strong particle formation events did occur for a considerable fraction of measurement time above $8 \mathrm{~km}$ (and only there). Very low concentrations were observed in general in the fresh outflow of active MCSs, likely as the result of efficient wet removal of aerosol particles due to heavy precipitation inside the convective cells of the MCSs. This wet removal initially affects all particle size ranges as clearly shown by all measurements in the vicinity of MCSs.

\section{Introduction}

The African tropical regions are critical for climate because the high solar irradiance and humidity make this region important for determining the global oxidative capacity and hence the lifetime of some greenhouse gases. The tropics are also an important source of gases and aerosols from biogenic emissions (Guenther et al., 1995), biomass burning (Hao and Liu, 1994), industrial and urban areas (Aghedo et al., 2007; van Aardenne et al., 2001), and aeolian erosion (Goudie, 1992; N'Tchayi Mbourou, G., 1997; N'Tchayi Mbourou, 1994).

The West African Monsoon (WAM) leads to a strong zonal gradient in precipitation and consequently vegetation. This is characterised by forest along the Guinea coast, shrub and grasslands in the Sahel, with bare soil and desert in the north of the region. The onset of the monsoon is typically in June, with the wet season associated with the northernmost position of the Inter-Tropical Convergence Zone (ITCZ). In the lower troposphere (LT) the wind flow is characterised by the south-westerly, moist and relatively cool monsoon flow and the north-easterly, dry, warm Harmattan wind which meet at the Inter-Tropical Discontinuity (ITD). Above the monsoon flow is the African Easterly Jet (AEJ) (Thorncroft and Blackburn, 1999; Parker et al., 2005; Thorncroft et al., 2003) at around $600 \mathrm{hPa}$, whilst in the upper troposphere (UT) there is the Tropical Easterly Jet (TEJ) (Peyrille et al., 2007). Deep convection occurs in organised systems known as Mesoscale Convective Systems (MCS) (Mathon and Laurent, 2001). Deep convection in the tropics associated with the ITCZ can lead to the rapid uplift and large-scale redistribution of gaseous pollutants and aerosols.

Model studies suggest biogenic emissions of volatile organic compounds (VOCs) from West Africa to be important for tropospheric ozone (Aghedo et al., 2007; Pfister et al., 2008). However measurements of biogenic VOCs (BVOCs) from African vegetation have previously been focussed in southern (Otter et al., 2003; Greenberg et al., 2003; Otter et al., 2002; Guenther et al., 1996) and central Africa (Serca et al., 2001; Guenther et al., 1999; Greenberg et al., 1999; Klinger et al., 1998). BVOCs are also important in formation of secondary organic aerosols (SOA) (Kavouras et al., 1998). The vegetation can also act as a rapid sink for ozone via dry deposition (Cros et al., 2000).

The West African region can also be a source of biogenic nitrogen oxides $\left(\mathrm{NO}_{\mathrm{x}}\right)$ both from soils (Jaegle et al., 2004) and from lightning (Schumann and Huntrieser, 2007). Note that both these sources are linked to the meteorology, with the emissions from Sahel soils triggered by the wetting of soils by precipitation, particularly at the onset of the wet season, and the lightning often associated with the MCSs.

Biomass burning in West Africa is linked to agricultural practice at latitudes south of $10 \mathrm{~N}$. Its pattern follows a well determined annual cycle related to the seasonal shift in the ITCZ. In the wet season, the peak emissions of anthropogenic biomass burning aerosol and trace gases occur in the southern Hemisphere, outside of W. Africa, between the equator and $10^{\circ} \mathrm{S}$ (Hao and Liu, 1994). However vertical profiles of ozone observed above Lagos (Sauvage et al., 2005) and elsewhere in Africa (Nganga et al., 1996) suggest biomass burning in the southern hemisphere can have a widespread affect, even into the northern hemisphere and over West Africa.

Aerosols are known to significantly affect the solar and terrestrial radiation budget and the cloud properties of the African region at the regional scale thereby modifying the planetary albedo and the outgoing long-wave radiation, reducing the radiation flux available to the surface, heating the atmosphere and impacting the dynamics of the synoptic flow, interacting with the ITCZ and the monsoon cycles (Forster et al, 2007; Denman et al, 2007). Intense source regions as well as horizontal transport processes near such sources can be identified by radiometry from satellite (Generoso et al., 2003, 2008; Legrand, 1997), but one of the main difficulties remains to precisely identify the characteristics of particles and their vertical extent, which is critical for their dispersion in the atmosphere and the estimation of their radiative impact. To date, little is known about aerosol emissions and properties in West Africa and their spatial and temporal variability (Echalar et al., 1995; Formenti et al., 2003; Haywood et al., 2003; Yoshioka et al., 2005). Amongst the major areas of uncertainties remain: (i) the contribution of soil erosion by 
mesoscale convective systems in the Sahel to the global budget of mineral dust (Tegen and Fung, 1995; Yoshioka et al., 2005); (ii) the processes leading to the emission of organic aerosols from vegetation and biomass burning, and the partitioning between primary and secondary formation are far from being elucidated (Volkamer et al., 2006; Kanakidou et al., 2005).

During June, July and August 2006 a multi-aircraft campaign took place over West Africa to observe the aerosol content and chemical composition of the troposphere and lower stratosphere as part of the African Monsoon Multidisciplinary Analysis (AMMA) project (Redelsperger et al., 2006; Lebel et al., 2009). These measurements on board 5 research aircraft provide the first detailed, in-situ characterisation of the aerosol and trace gas composition of the troposphere in this region. The aircraft were equipped with instruments to make measurements of ozone $\left(\mathrm{O}_{3}\right)$, many of its precursor species (e.g. carbon monoxide (CO), $\mathrm{NO}_{\mathrm{x}}$ and VOCs), as well as photochemical products (e.g. radical species and oxygenated VOCs (OVOCs)) and properties and composition of atmospheric aerosols. Details of the meteorological situation over West Africa during the summer of 2006 are given in Janicot et al. (2008).

The aim of this paper is to provide an overview of the flights made by the 5 research aircraft and to provide the first comprehensive characterisation of aerosols and trace gases over West Africa during the monsoon period. The scientific questions that the aircraft campaigns addressed are given below. This paper focuses on the average patterns observed, and in particular those gained by looking at the data across several measurement platforms, and how these address the scientific questions. More detailed or case studies which address individual aspects of the scientific questions are dealt with by other papers, as indicated below. In this paper the aircraft data are also compared to other data sets that are available for this region from ozone sondes and satellites.

One of the main questions was the role of natural versus anthropogenic emissions from $\mathrm{W}$. Africa on the oxidizing capacity of the atmosphere. What evidence was there for extensive emissions of BVOCs and to what degree were they transported throughout the troposphere (Bechara et al., 2009; Garcia-Carreras et al., 2010; Murphy et al., 2010)? Were the observed BVOC distributions consistent with that expected from emission models (Ferreira et al., 2010)? Could emissions of $\mathrm{NO}_{\mathrm{x}}$ from recently wetted soils be detected in the boundary layer and what was the impact on ozone (Delon et al., 2008; Stewart et al., 2008)? Were major coastal cities such as Lagos a large source of ozone precursors (Hopkins et al., 2009; Minga et al., 2010)?

Another issue was the impact of biomass burning emissions from the southern hemisphere on the tropospheric composition over W. Africa. Could the impact implied by ozone soundings be confirmed by observations of biomass burning tracers (Murphy et al., 2010)? How widespread was the effect and what were the routes by which these pollutants were being transported into W. Africa (Mari et al., 2008; Real et al., 2010; Thouret et al., 2009; Williams, 2010; Fiedler et al., 2010)? What are the physico-chemical properties of biomass burning aerosols, in particular their composition (Matsuki et al., 2010a)?

A key area of study was the role of convection on redistributing pollutants and its impact on oxidants and aerosols in the upper troposphere and lower stratosphere. What are the roles of convective physical processes, vertical transport and mixing on the budget of major oxidants and aerosols in the free troposphere over West Africa (Ancellet et al., 2009; Bechara et al., 2009; Fierli et al., 2010; Law et al., 2010; Homan et al., 2010)? How do deep convective processes influence the distributions of chemical constituents in the tropical tropopause layer (TTL) compared to other transport processes (Barret et al., 2008; Barret et al., 2010; Fierli et al., 2010; Homan et al., 2010; Law et al., 2010; Mari et al., 2008; Real et al., 2010; Williams, 2010; Schiller et al., 2009; Voigt et al., 2008; Palazzi et al., 2009)? What is the composition of the lowermost stratosphere and to what extent is it influenced by local convection (Fierli et al., 2010; Khaykin et al., 2009; Borrmann et al., 2010; Liu et al., 2010)?

Overall, what are the impacts of all these emission sources on the major sources and sinks of the oxidants over W. Africa (Saunois et al., 2009; Stone et al., 2010; Andrés-Hernández et al., 2010; Commane et al., 2010)? What are the relative roles of the anthropogenic and natural emissions on the tropospheric oxidant loading (Saunois et al., 2009; Williams, 2010; Williams et al., 2009)? What is the impact of the production of $\mathrm{NO}_{\mathrm{x}}$ from lightning within the convective systems on ozone formation (Andres-Hernandez et al., 2009; Barret et al., 2010; Williams et al., 2009)?

Regarding aerosols, a key issue was the potential for secondary organic particle formation from biogenic and anthropogenic gas-phase precursors (Capes et al., 2009) and for aerosol nucleation in the free troposphere. Attention was given to investigating the emission processes and properties of mineral dust. It was considered important to better understand the processes leading to dust emissions and the vertical redistribution of dust after emission, in particular with respect to the role of convective systems and of vegetation heterogeneities (Bou Karam et al., 2008; Bou Karam et al., 2009; Crumeyrolle et al., 2008, 2010; Flamant et al., 2007; Flamant et al., 2009a, b; Marsham et al., 2008). An outstanding issue was the physico-chemical properties driving the climatic impacts of mineral dust, in particular with respect to their variability between Saharan and Sahelian sources, emission versus transport conditions, and modifications of hygroscopic properties induced by cloud-processing (Crumeyrolle et al., 2008; Formenti et al., 2010; Matsuki et al., 2010a, b). 
Table 1. Aircraft detachment periods for each SOPs $1 \& 2$. The names of the aircraft campaigns that took place within the wider AMMA SOPs were given the suffixes " $a N$ " where " $a$ " signifies "aircraft" and " $N$ " is the number of the aircraft campaign within that SOP. Operational bases are colour-coded (red = Niamey, blue $=$ Dakar, yellow $=$ Ouagadougou $)$.

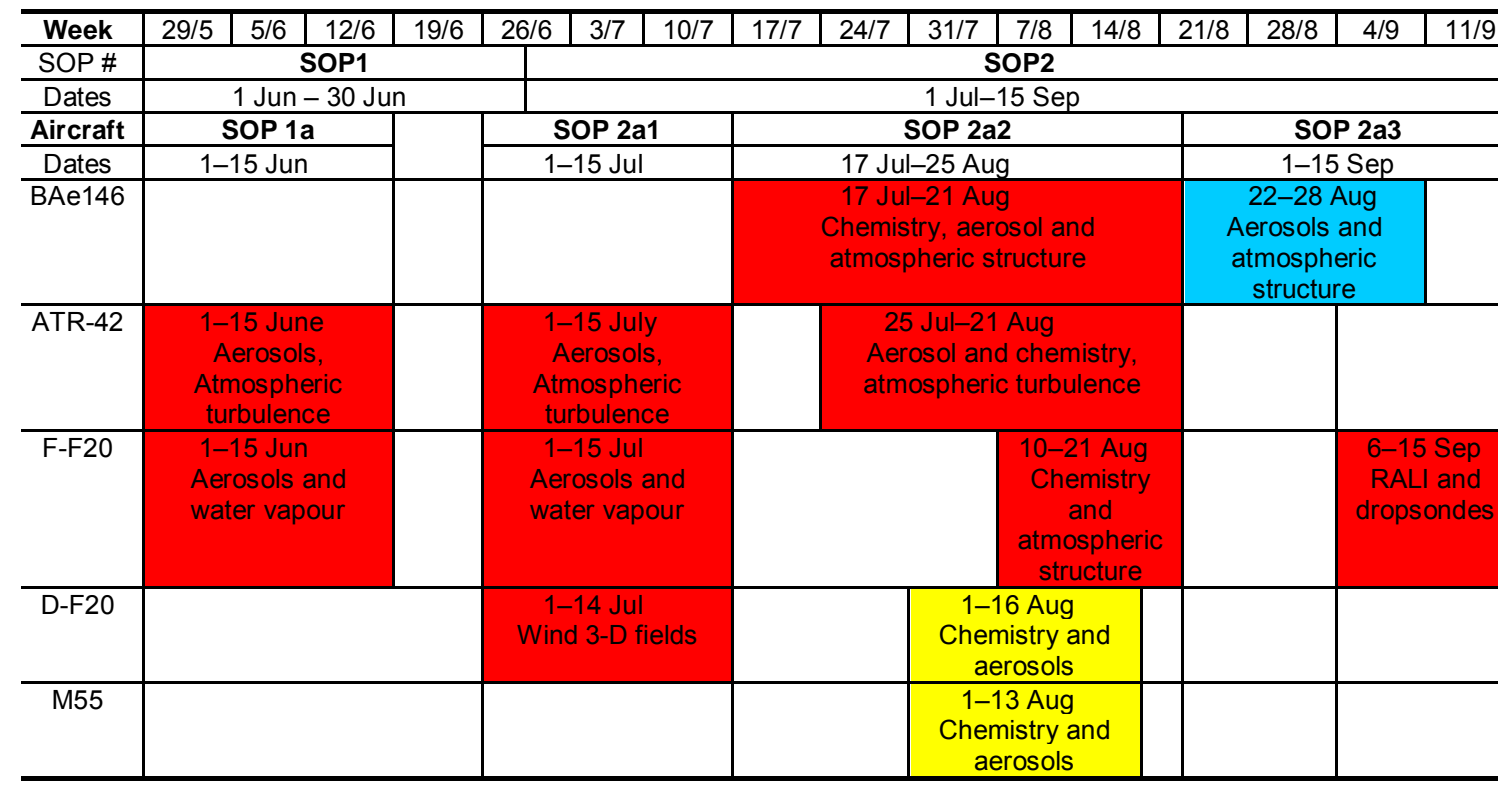

\section{Field campaign}

\subsection{Flying programme}

The AMMA field measurement programme was divided into several different types of observational periods (International Science Plan, http://science.amma-international.org/science/ docs/AMMA_ISP_May2005.pdf) (Table 1). The measurements presented here are from the Special Observational Periods 1 and 2 (SOP 1 and SOP 2). SOP1 targeted the preonset period of the Monsoon development in June. SOP2 then followed and targeted the monsoon onset and maximum in July and August 2006 with the aircraft instrumented for chemical measurements.

During June, July and August 2006 five research aircraft (three based in Niamey, Niger: FAAM BAe-146, SAFIRE Falcon (F-F20) and ATR-42; and two in Ouagadougou, Burkina Faso: DLR Falcon (D-F20) and Geophysica (M55) (Table 2) made comprehensive measurements of aerosols and trace gases from the boundary layer to the lower stratosphere (around $50 \mathrm{hPa}$ ), from $2^{\circ} \mathrm{N}$ to $21^{\circ} \mathrm{N}$, and between $10^{\circ} \mathrm{W}$ and $7^{\circ} \mathrm{E}$. The horizontal and vertical ranges covered by each aircraft are illustrated in Fig. 1. The ATR-42 focussed on the lower troposphere, the BAe-146 on the lower and mid-troposphere, the two Falcons on the upper troposphere and the M55 on the upper troposphere/lower stratosphere (UTLS). In combination this provides coverage throughout the full depth of the troposphere.
As part of the coordinated flight planning several different flight strategies were designed to address different scientific questions. Each of these flight strategies was called an Intensive Observational Period (IOP). The types of IOPs flown during SOP1 and SOP2 are given in Table 3. IOP1.1 was aimed at exploring of the inter-tropical front (ITF) and surveying of the spatial and temporal evolution of the atmosphere in the coupled monsoon-harmattan-AEJ system. IOP1.2 focussed on the description of the role of mesoscale convective systems on the emission budget of mineral dust from the Sahel. IOPs 1.4, 1.5 and 1.6 were designed to investigate the impact of local (W. African) emissions on the chemical composition of the PBL. In particular, IOPs 1.4 and 1.5 aimed at investigating the impact of biogenic emissions from soils of different moisture characteristics from different vegetation types, while IOP1.6 targeted anthropogenic emissions from urban areas. IOP2 was aimed at investigating the impact of MCSs on the transport and transformation of pollutants in air as it was convectively uplifted. This included coordinated flights with some aircraft probing the PBL prior to uplift and others sampling the UT in regions of detrainment. IOP3 targeted air masses undergoing long range transport, either into the $\mathrm{W}$. African region (e.g. biomass burning plumes from the southern hemisphere) or those in the UT following convective uplift some days previously. In addition to these targeted studies, data were also collected throughout the different flights to build up a large scale picture of the chemical composition and processing of air over W. Africa. 

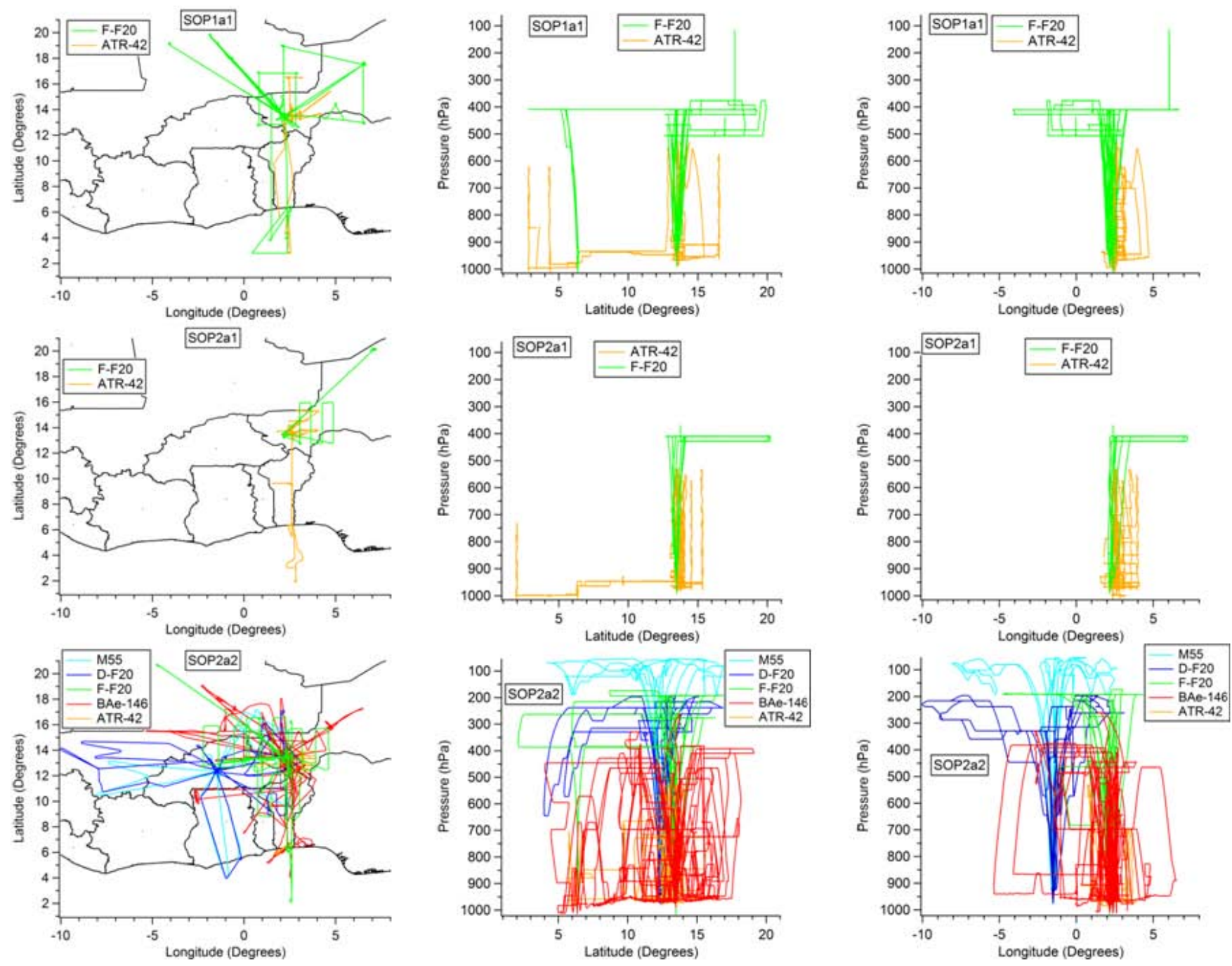

Fig. 1. Flight tracks of the 5 research aircraft during SOPs 1a1 (top), 2a1 (middle) and 2a2 (bottom).

Table 2. Aircraft capabilities.

\begin{tabular}{llllll}
\hline Aircraft & F-F20 & ATR-42 & BAe-146 & D-F20 & M55 \\
\hline Operating altitude (km) & $0.15-13$ & $0.15-8$ & $0.015-11$ & $0.015-12$ & $15-22$ \\
Payload (kg) & 1200 & 2500 & 4000 & 1200 & 1500 \\
Range (km) & 3200 & 3000 & 3700 & 3200 & 3500 \\
Staffing & 3 crew, 2 scientists & 3 crew, 7 scientists & 3 crew, 18 scientists & 3 crew, 3 scientists & 1 crew \\
Duration (hrs) & 4 & 4 & 5.5 & $3-4$ & 5.5 \\
Ground speed (m/s) & $170-200$ & 95 & $120-180$ & $170-240$ & 210 \\
\hline
\end{tabular}

Table 1 of the Supplementary Information shows when each aircraft flew and which IOP was addressed by each flight, whilst Tables 2a-e of the Supplementary Information give details about each flight aircraft by aircraft. In all a total of 107 science flights were made involving over 389 hours of flying time.

\subsection{Aircraft payloads}

The aircraft were fitted with a range of instrumentation for measuring chemical species (Tables 3a-e of the Supplementary Information). 
Table 3. Intensive Observational Periods (IOPs). The IOP numbering system is based on that widely used in the implementation of the AMMA programme. Flights relating to the IOPs listed were flown during the campaigns when the aircraft were fitted with instrumentation for chemical and aerosol measurements.

\begin{tabular}{ll}
\hline IOP & Description \\
\hline 1.1 & $\begin{array}{l}\text { Surface-atmosphere: Inter-tropical front and heat low } \\
\text { surveys }\end{array}$ \\
1.2 & $\begin{array}{l}\text { Surface-atmosphere-aerosol: Squall-line related } \\
\text { aerosol emissions surveys }\end{array}$ \\
1.3 & $\begin{array}{l}\text { Surface-atmosphere } \\
\text { atmosphere interactions surveys }\end{array}$ \\
1.4 & Surface-atmosphere: Land-atmosphere interactions \\
1.5 & Vegetation and soil emission surveys \\
1.6 & Urban surveys \\
1.7 & Aerosol mixing and hygroscopicity \\
1.8 & Turbulence \\
2 & Dynamics and chemistry of Mesoscale Convective \\
3 & Systems (MCS) \\
6 & Long range transport surveys \\
\end{tabular}

\subsection{Flight planning}

Flights were planned using a number of tools depending on the IOP to be flown. Meteorological forecast reports were provided by a team of local forecasters at ACMAD (African Centre of Meteorological Application for Development). These indicated the predicted positions of such features as the AEJ, the TEJ, the ITD, African Easterly Waves (AEW) and organised convection at 06:00 and 18:00 UTC. Meteosat infra-red images were used for now-casting the location of MCSs, which was particularly useful for IOP2. Trajectories calculated from ECMWF data were used for planning IOP3 (long range transport). Flight planning for IOP1.4 used near real-time Land Surface Temperature Anomaly data derived from LandSAF (http://landsaf.meteo.pt/) to identify regions of recent precipitation and for IOP1.5 MODIS tree cover data from Land Processes Distributed Active Archive Center (http://lpdaac.usgs.gov) was used.

One Chemical Transport Model (LMDz-INCA) and one regional model (Meso-NH) driven by ECMWF meteorological products delivered chemical, biogenic and lightning tracers forecast continuously during the mission. A Lagrangian model, FLEXPART-GIRAFE, was used to track the biomass burning plumes from the southern hemisphere (Mari et al., 2008). MOPITT data were also available in near real-time over West Africa.

\section{Intercomparison of aircraft data}

The airborne observation dataset from AMMA was collected from several different aircraft operated in different locations and at different times. The true value of the complete dataset can only be realised if the measurements are integrated together in a consistent manner. The assimilation of the data must take account of the uncertainty in the measurements associated with systematic and random errors estimated for each instrument. It is essential to estimate these errors in an operating environment, which for aircraft entails wingtip-towingtip comparison flights along straight and level runs at various altitudes.

On 16 August 2006 four of the aircraft participated in a comparison flight to the west of Niamey. The BAe-146 flew alongside three aircraft in turn at a variety of altitudes: the D-F20, F-F20 and ATR42. Therefore, differences between measurements are all estimated relative to the BAe-146 measurements. For details of the flights and how the data were processed see Appendix A.

Table 4 shows the mean, standard deviation and rank correlation between the time series from all comparable instruments on the different aircraft during the formation flight segments. Longitude and latitude measurements have an insignificant bias with an average difference of approximately $40 \mathrm{~m}$, consistent with the aircraft separation. Measurements of static pressure do indicate small biases, the largest being between the ATR-42 and BAe-146 (3.6 hPa). However on this comparison the BAe146 was flying slightly higher than the ATR- 42 as a precaution of the turbulence experienced at $0.9 \mathrm{~km}$ altitude. The turbulence also accounts for the lower pressure correlation between these two aircraft.

From the initial comparison an error was identified in the processing to obtain wind components for the BAe-146, accounting for aircraft motion. This was corrected and the comparison re-performed as shown in Table 4. Mean and standard deviation of the differences are less than $1 \mathrm{~m} \mathrm{~s}^{-1}$. Wind data from the F-F20 was not submitted for comparison.

Temperature differences were approximately $1 \mathrm{~K}$ and relative humidity $(\mathrm{RH})$ differences were a few percent. It is worth noting that on the comparison legs $\mathrm{RH}$ varied between 40 and $85 \%$ with rapid fluctuations at FL190. On the profiles very thin cirrus cloud layers were crossed and these fluctuations are likely to be associated with old cirrus layers. Relative humidity with respect to ice was measured on the highest legs (FL190) and with respect to liquid water below this.

Differences in ozone measurements were lower than during comparison flights from previous campaigns (e.g., ICARTT; Fehsenfeld et al., 2006) with means and standard deviations of only 1 ppbv. Figure 2 compares the ozone time series from all 4 aircraft during the comparison legs. Note that the time stamp from the F-F20 instrument had not been synchronised and suffered an obvious lag of 60 s which has been corrected for in Table 4 and Fig. 2. 
Table 4. Results from comparison flight legs in formation with BAe-146. For each aircraft, the difference from the BAe-146 measurement is summarised by its mean, standard deviation and rank correlation $(R)$. A running median filter with a window width of $10 \mathrm{~s}$ was applied to all data before putting on common time-base.

\begin{tabular}{lllllllllll}
\hline Variable & Units & \multicolumn{3}{c}{ D-F20 } & \multicolumn{3}{c}{ F-F20 } \\
\hline & & mean & sdev & $R$ & mean & sdev & $R$ & mean & sdev & $R$ \\
Longitude & $\mathrm{deg}$ & 0.00016 & 0.00102 & 1.000 & 0.00025 & 0.00102 & 1.000 & 0.00015 & 0.00044 & 1.000 \\
Latitude & $\mathrm{deg}$ & -0.00022 & 0.00037 & 1.000 & 0.00015 & 0.00077 & 1.000 & 0.00012 & 0.00069 & 0.994 \\
Pressure & $\mathrm{hPa}$ & -0.93 & 0.29 & 0.978 & -1.18 & 0.18 & 0.949 & 3.61 & 0.32 & 0.663 \\
$\mathrm{U}$ & $\mathrm{m} \mathrm{s}^{-1}$ & 0.17 & 0.33 & 0.989 & & & & 0.15 & 0.65 & 0.957 \\
$\mathrm{~V}$ & $\mathrm{~m} \mathrm{~s}^{-1}$ & -0.23 & 0.40 & 0.982 & & & & -0.21 & 0.42 & 0.890 \\
Temperature & $\mathrm{K}$ & -0.09 & 0.13 & 0.999 & 1.11 & 0.22 & 0.996 & -0.83 & 0.09 & 0.976 \\
$\mathrm{RH}$ & $\%$ & 2.4 & 3.3 & 0.973 & -1.6 & 2.6 & 0.962 & -3.4 & 1.7 & 0.914 \\
Ozone & $\mathrm{ppbv}$ & 0.1 & 0.9 & 0.936 & -2.4 & 1.0 & 0.980 & 1.2 & 1.4 & 0.763 \\
CO & $\mathrm{ppbv}$ & 0.1 & 4.3 & 0.906 & 4.7 & 4.6 & 0.715 & 18.1 & 7.1 & 0.746 \\
\hline
\end{tabular}

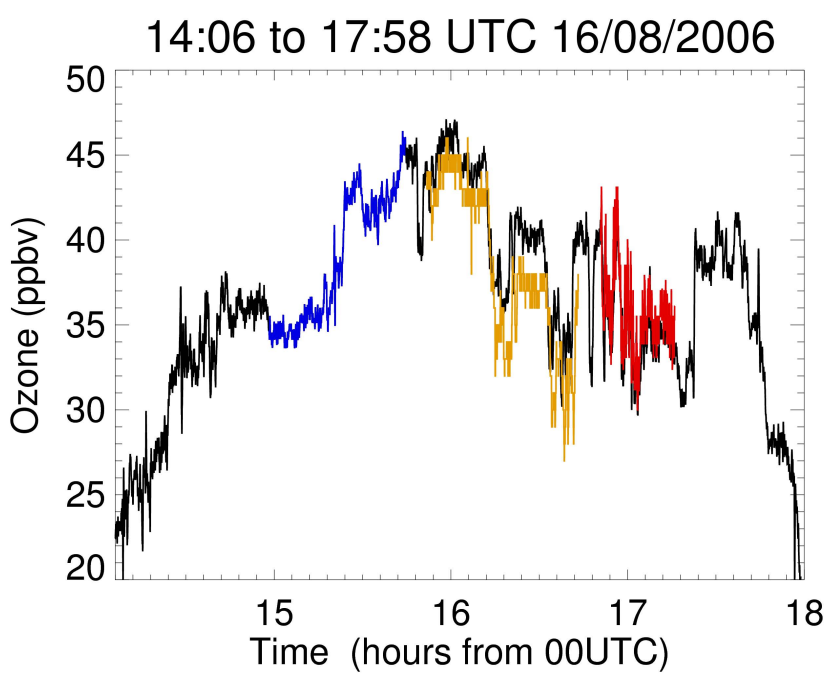

Fig. 2. Comparison of ozone measured on board the BAe-146 (black), D-F20 (blue), F-F20 (brown) and ATR42 (red) during wing-tip to wing-tip flights.

The initial carbon monoxide comparison was much worse than had been observed in previous campaigns (e.g., ICARTT). This motivated a comparison of the CO-standards used during AMMA against two NOAA standards. The percentage differences of the measured concentration of each AMMA standard from its quoted concentration were: $-0.3 \%$ for D-F20, $+6.9 \%$ for BAe-146 and $-7.2 \%$ for the F-F20. The comparison of $\mathrm{CO}$ mixing ratios is shown in Table 4 after multiplying the time series by the appropriate scaling factors: D-F20 (0.997), BAe-146 (1.069) and F-F20 (0.928). The correction eliminates the bias between the D-F20 and BAe-146 measurements, but the F-F20 measurements remain high relative to the BAe-146 $\mathrm{CO}$, although comparable with the standard deviation in the case of the F-F20. These scaling factors have been applied to the data before integrating them
Table 5. Results from comparison flight legs between BAe-146 and D-F20 in formation. The mean and standard deviation of BAe146 measurements is shown. The difference between D-F20 and BAe-146 is summarised by its mean, standard deviation and rank correlation $(R)$. A running median filter with a window width of $10 \mathrm{~s}$ was applied to all data before putting on common time-base.

\begin{tabular}{lllllll}
\hline Variable & Units & \multicolumn{2}{c}{ BAe-146 } & \multicolumn{3}{c}{ D-F20 } \\
\hline & & mean & sdev & mean & sdev & $R$ \\
$\mathrm{CO}_{2}$ & ppmv & 373.6 & 1.4 & 1.1 & 0.8 & 0.756 \\
$\mathrm{NO}_{\mathrm{y}}$ & pptv & 276 & 92 & 32 & 97 & 0.828 \\
$\mathrm{HCHO}$ & pptv & 372 & 51 & 13 & 42 & 0.374 \\
\hline
\end{tabular}

together to create average plots. The ATR-42 standard was not involved in the comparison, so CO data from the ATR-42 are not included in this analysis.

Additional measurements were available for comparison between the BAe-146 and D-F20 (Table 5). The mean and standard deviation between $\mathrm{CO}_{2}$ measurements is approximately 1 ppmv and therefore of the same order as the standard deviation in the time series itself since $\mathrm{CO}_{2}$ has a small dynamic range. Nevertheless the correlation is almost as high as for $\mathrm{CO}$.

Averaging across the entire comparison window the mean difference between $\mathrm{NO}_{\mathrm{y}}$ measurements is approximately $12 \%$. The correlation is also high. However, the BAe-146 measurement showed less dynamic range, reporting of the order $100 \mathrm{pptv}$ higher at $697 \mathrm{hPa}$ and $100 \mathrm{pptv}$ lower at $485 \mathrm{hPa}$. The reasons for this have not been resolved and the comparison was not as good as when the UK instrument was installed on the Met Research Flight C130 aircraft (Brough et al., 2003).

Formaldehyde (HCHO) mixing ratios have only been compared on the profile ascent and higher flight leg $(485 \mathrm{hPa})$ 
because the BAe-146 data showed an unrealistic oscillation on the lower leg.

A comparison has also been made of peroxy radicals as measured on board the BAe-146 using the FAGE (Laser induced fluorescence) (Heard, 2006) $\left(\mathrm{HO}_{2}\right.$ only) and by PERCAs (Peroxy Radical Chemical Amplifier) $\left(\mathrm{RO}_{2}+\mathrm{HO}_{2}\right)$ on board both the BAe-146 (Green et al., 2006) and the D-F20 Falcon (Andres-Hernandez et al., 2009). The results are reported in Andres-Hernandez et al. (2010).

The intercomparison exercise for aerosols concerned only three aircraft, the BAe-146, the D-F20 and the ATR-42 (the F-F20 did not carry any in situ aerosol instrumentation). Intercomparing aerosol measurements onboard aircraft is challenging for a number of reasons (see Appendix A) and as a consequence, the different aerosol datasets have not been merged to provide mean patterns but, whenever appropriate, they have instead been used individually to answer specific science questions.

\section{Overview of results}

\subsection{Large scale patterns of trace gases}

Figure $3 \mathrm{a}$ shows average $\mathrm{O}_{3}$ concentrations from the 5 aircraft plotted as a function of latitude and altitude. The averages are created by taking 1-min data for each flight from each aircraft, separating them into bins of $100 \mathrm{hPa}$ of atmospheric pressure and 1 degree of latitude and then calculating the mean. Figure $3 b$ is the same as $3 a$ except longitude bins are used instead of latitude bins. A number of features evident in the $\mathrm{O}_{3}$ distribution can be related to the dynamics of the region.

There is a general vertical gradient with concentrations declining towards the surface. A sharp gradient is observed around $100 \mathrm{hPa}$, with concentrations up to $1700 \mathrm{ppv}$ above in the lower stratosphere, whilst concentrations in the troposphere rarely exceed $100 \mathrm{ppbv}$. This vertical gradient largely reflects an anti-correlation with water vapour, with high concentrations of ozone in the drier stratosphere and lower concentrations in the humid monsoon layer air in the lower troposphere. The vertical gradient will be considered in more detail in Sect. 4.2.

Note that there is no obvious pattern of ozone concentration with longitude, at any altitude. However there are a couple of features that can be identified when looking at the latitude versus pressure plots. At low latitudes, around $650 \mathrm{hPa}$, air was sampled that contained higher concentrations of ozone than at other latitudes at similar pressures. This air also tended to be drier. It was influenced by biomass burning and had been advected into the region (see Sect. 4.3). A second feature is that at the lowest altitudes bins (pressure $>800 \mathrm{hPa}$ ) there is a tendency for concentrations of ozone to be lower in the moister air to the south and higher in the drier air to the north. Not only is the latitudinal gradient af-
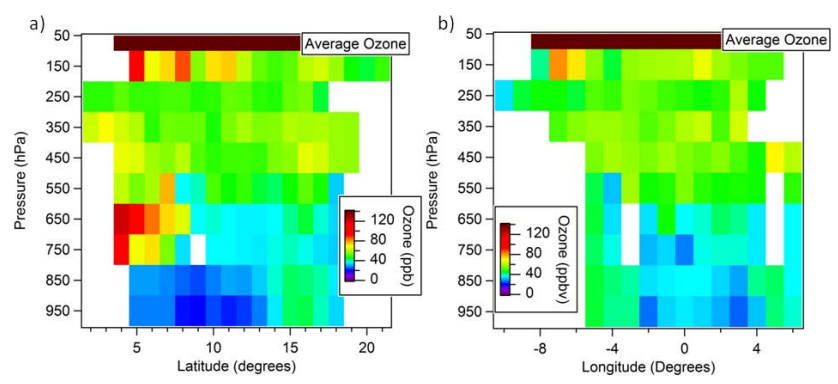

Fig. 3. Average ozone concentrations in bins of $100 \mathrm{hPa}$ of atmospheric pressure and (a) 1 degree of latitude and (b) 1 degree of longitude based on 1-min data from the BAe-146, the DLR Falcon, the French Falcon, French ATR and the M55 between 20 July and 21 August. Note that the ozone concentrations in the top layer are averages between of 100 and $50 \mathrm{hPa}$ and are off the colour scale, extending up to $1700 \mathrm{ppbv}$.
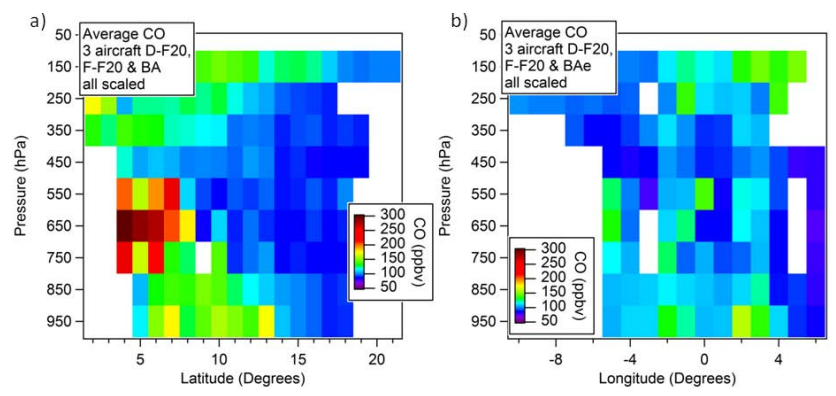

Fig. 4. Average $\mathrm{CO}$ concentrations in bins of $100 \mathrm{hPa}$ of atmospheric pressure and (a) 1 degree of latitude and (b) 1 degree of longitude based on 1-minute data from the BAe-146, DLR Falcon and French Falcon between 20 July and 21 August. Note that the concentrations have been scaled according to the comparisons of standards.

fected by the dynamics, but also by the land surface which transitions from ocean in the south, via mosaic forest and savanna to desert in the north. The impact of this on the chemical composition in the lower atmosphere is discussed in Sect. 4.5.

Figure 4 shows latitudinal and longitudinal average profiles of CO from the D-F20, F-F20 and BAe-146 scaled according to the results of the comparison of standards. There is no strong spatial pattern longitudinally; however there are a number of interesting features in the latitudinal profile. There is a tendency for higher concentrations in the south at all altitudes, except over the ocean in the boundary layer. In the lower troposphere the highest concentrations were found between $5^{\circ}$ and $13^{\circ} \mathrm{N}$ over the vegetated regions and urban regions. The influence of landing at Cotonou and a low level circuit of Lagos can be seen at $7^{\circ} \mathrm{N}$ and of landings at the aircraft bases of Ouagadougou and Niamey at $13^{\circ} \mathrm{N}$. The influence of the biomass burning plumes can be seen in the southerly region of the mid-troposphere. The 


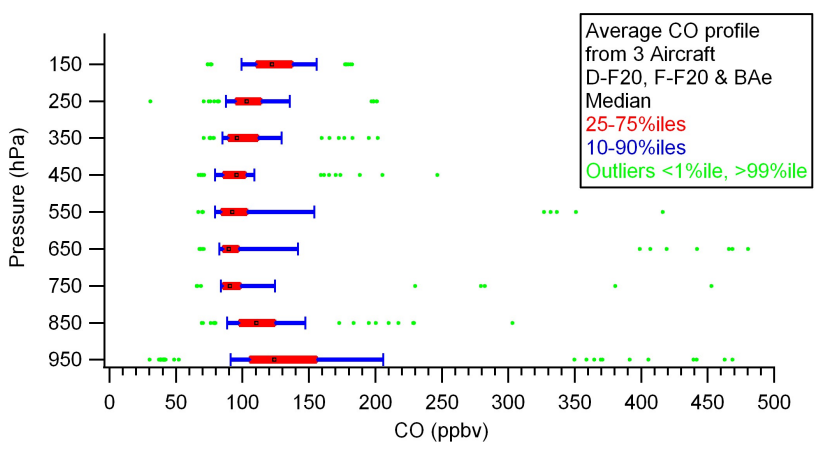

Fig. 5. Average vertical profile of $\mathrm{CO}$ concentrations in bins of $100 \mathrm{hPa}$ of atmospheric pressure based on 1-min data from the BAe146, the DLR Falcon and the French Falcon between 20 July and 21 August. The black marker is the median, the red box the range of the 25 to 75 percentiles, the blue whiskers the range of the 10 to 90 percentiles and the green points outliers less than the 1 percentile and greater than the 99 percentile. Note that the concentrations have been scaled according to the comparisons of standards.

average vertical profile of $\mathrm{CO}$ (Fig. 5), exhibits a " $\mathrm{C}$ " shape with highest median concentrations in the lower and upper troposphere. However the impact of biomass burning in the mid-troposphere is evident in the high values of the 90th percentiles and the outliers ( $>99$ th percentiles).

To put the aircraft data into the wider context, both spatially and temporally, and to help explain the features observed, they are compared to satellite measurements of $\mathrm{CO}$ from MOPITT (Emmons et al., 2009). Figure 6 shows the aircraft and satellite data in layers centred on $700 \mathrm{hPa}$ and $250 \mathrm{hPa}$. The MOPITT data are for August 2006, the month during which most of the aircraft flights were made.

At $700 \mathrm{hPa}$ the elevated CO seen by the aircraft is part of a large scale feature originating over the western part of southern Africa (centred around Angola and Zaire) and extending north westward into the Gulf of Guinea. The aircraft tended to observe higher $\mathrm{CO}$ in the southern legs of the flights than measured by satellite. Much of this is due to some flights targeting these southern hemispheric plumes. At $250 \mathrm{hPa}$ this feature, although much weaker, is still evident. It is not clear how much of this $\mathrm{CO}$ at $250 \mathrm{hPa}$ results from convective uplift of CO-rich air from W. Africa, or how much is due to long-range upper tropospheric transport into the region following up-lift elsewhere. Either way, the satellite data suggests that emissions in southern Africa contributed to elevated $\mathrm{CO}$ throughout much of the troposphere along the Gulf of Guinea coast.

At $250 \mathrm{hPa}$ the aircraft tended to observe higher $\mathrm{CO}$ in the region $4-10^{\circ} \mathrm{N}$ than measured by satellite, largely because many of the flights at this altitude where aimed at sampling outflow from MCSs. There is sparse data coverage from the satellite in this zone due to the frequent occurrence of cloud, however there is still some suggestion of elevated $\mathrm{CO}$ in this region, certainly compared to further north. The source of
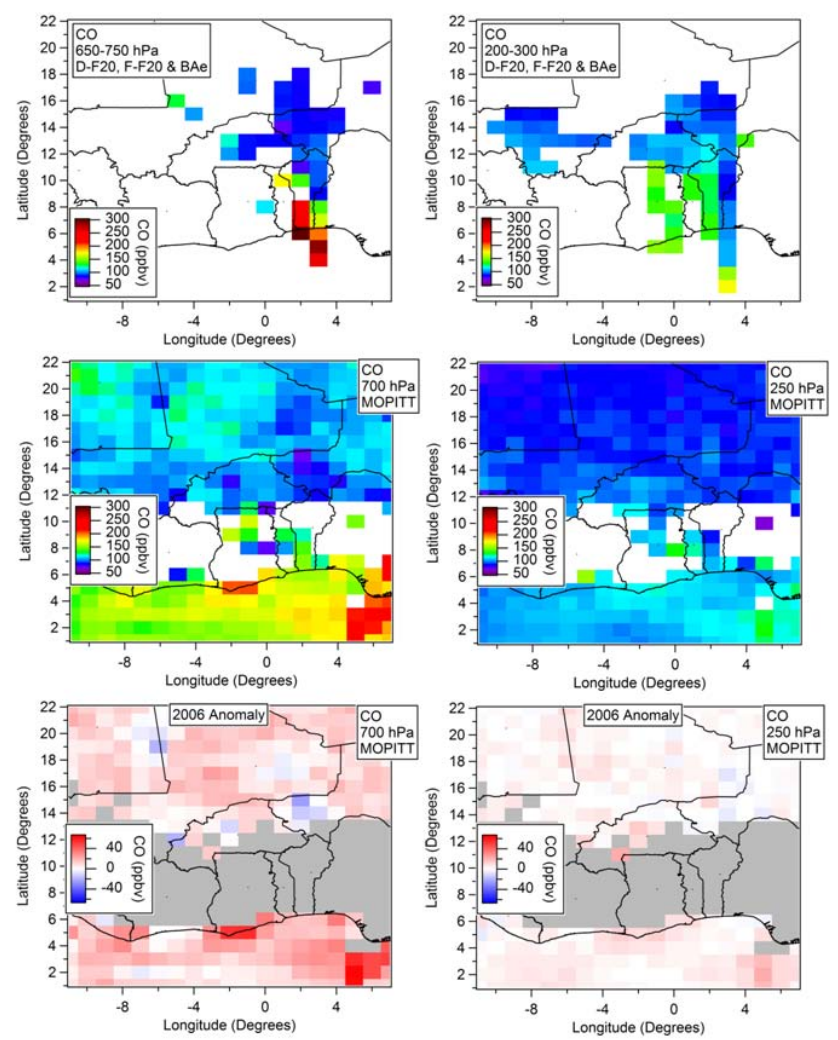

Fig. 6. Top panel: average $\mathrm{CO}$ concentrations based on 1-min data from the BAe-146, DLR Falcon and French Falcon between 20 July and 21 August for the layers $650-750 \mathrm{hPa}$ (left) and $200-300 \mathrm{hPa}$ (right). Note that the concentrations have been scaled according to the comparisons of standards. Middle panel: average CO concentrations for August 2006 from MOPITT for the levels $700 \mathrm{hPa}$ (left) and $250 \mathrm{hPa}$ (right). Lower panel: MOPITT CO anomalies for August 2006 compared to the average for the years 2000-2008 (excluding 2001) for the levels $700 \mathrm{hPa}$ (left) and $250 \mathrm{hPa}$ (right).

this CO is discussed in several papers (Barret et al., 2008; Ancellet et al., 2009; Law et al., 2010).

At $700 \mathrm{hPa}$ the aircraft data suggest slightly higher CO concentrations in the north-west of the region. This is in agreement with the satellite data which shows extensive regions of $\mathrm{CO}$ above $100 \mathrm{ppbv}$ across northern Africa, with a hot spot over Sudan (not shown).

Comparing the MOPITT data for August 2006 with Augusts of previous years (2000-2008, excluding 2001 for which there is insufficient data) (Fig. 6, bottom panel), it can be seen that at $700 \mathrm{hPa}, \mathrm{CO}$ was considerably higher than in other years. As an average for the region shown in the figure it was $10 \mathrm{ppbv}$ above the mean. This anomaly is highest in the south of the region with values up of $60 \mathrm{ppbv}$. It suggests that the influence of biomass burning in the southern hemisphere on $\mathrm{CO}$ in the lower troposphere over the West African region was greater in 2006 then is typical of recent years. Note that the CO in the north of the region at this altitude 

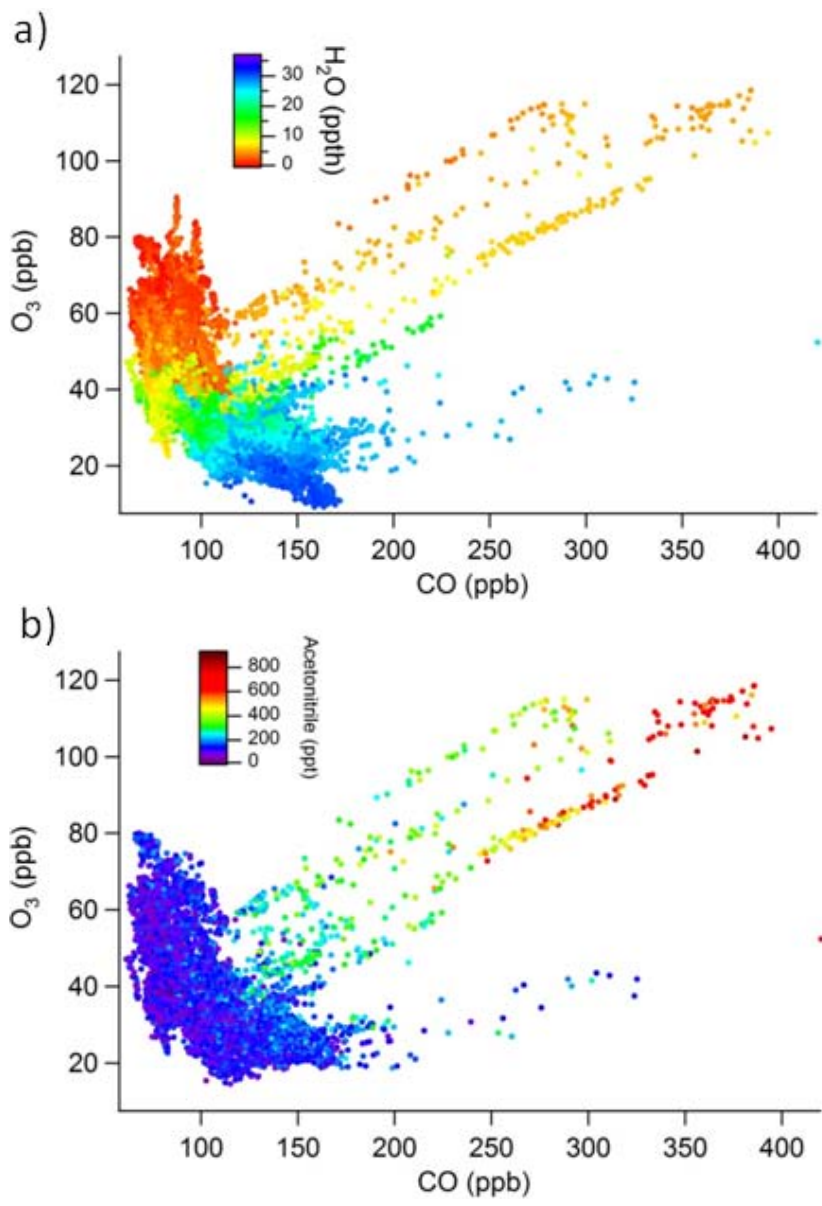

Fig. 7. Ozone and CO correlations coloured by a) water vapour and b) acetonitrile. Data from the BAe-146 only.

in 2006 was also higher than the mean. Unlike $700 \mathrm{hPa}, \mathrm{CO}$ at $250 \mathrm{hPa}$ in August 2006 was close to the mean of recent years.

Figure 7 shows the relationship between ozone and $\mathrm{CO}$ (for the BAe-146 data only). The bulk of the data falls into a population where there is a negative correlation between these two chemical compounds. This correlation is related to water vapour in that the air with higher ozone and lower $\mathrm{CO}$ concentrations tends to be drier, whilst the air with lower ozone and higher $\mathrm{CO}$ concentrations tends to be moister. This illustrates the stratospheric source of tropospheric ozone and the relatively short photochemical lifetime of ozone in the moist, monsoon layer air into which $\mathrm{CO}$ is emitted. A second population of data shows a positive relationship between ozone and $\mathrm{CO}$. It occurs at a range of water vapour concentrations and typically displays a ratio of 1 ozone molecule to $4 \mathrm{CO}$ molecules. This population can be subdivided into 2 groups: 1 that is influenced by biomass burning as indicated by the elevated concentrations of acetonitrile (Murphy et al., 2010) (Fig. 7b) and is in relatively dry air and 1 that does not show increased acetonitrile but
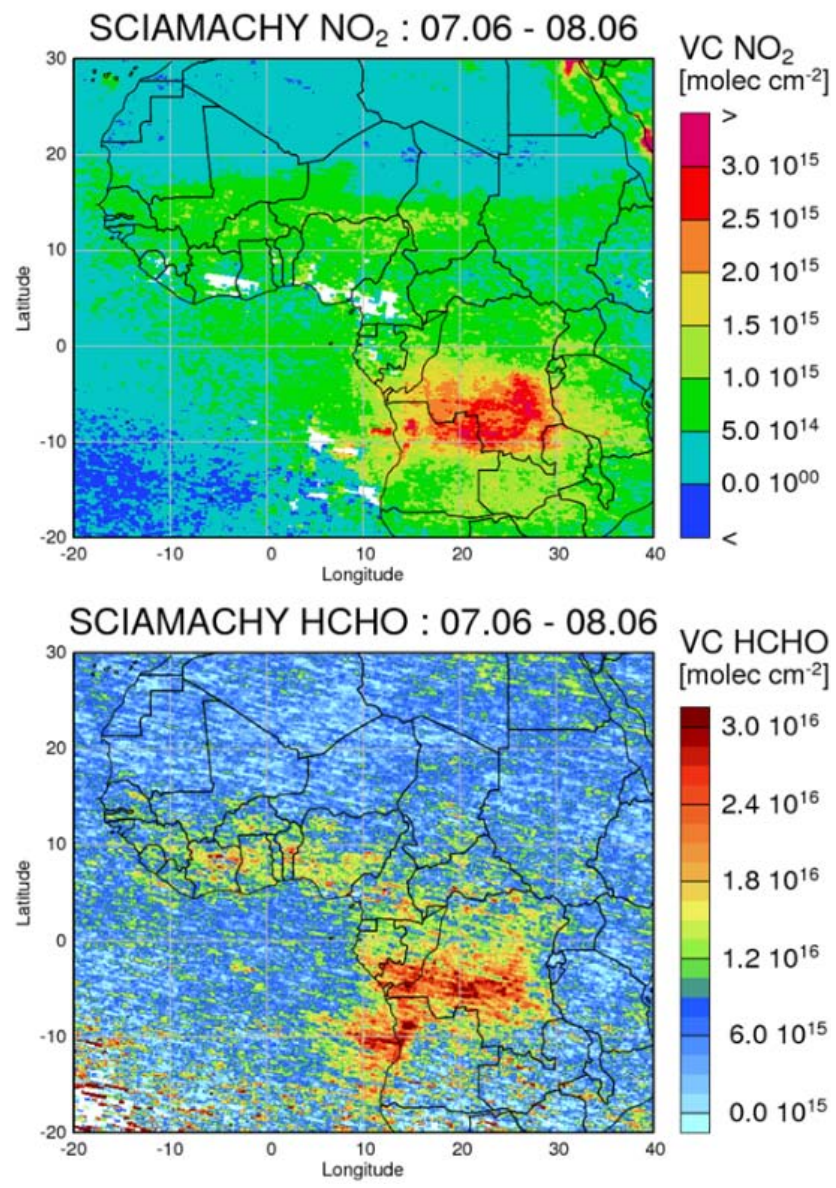

Fig. 8. Average tropospheric column densities of $\mathrm{NO}_{2}$ (top) and HCHO (bottom) for July and August 2006 from SCIAMACHY.

is due to anthropogenic (non-biomass burning) emissions as observed in a flight in the moist boundary layer around Lagos, Nigeria. Figure 7 suggests that with the exception of a few polluted air masses where there were clear enhancements of ozone with increased levels of $\mathrm{CO}$ (e.g. the Cotonou/Lagos city plume as discussed in Ancellet et al., 2009), most of the air sampled over W. Africa shows a tendency for net photochemical loss of ozone.

Measurements from the satellite instrument SCIAMACHY can be used to get a picture of the overall distribution of $\mathrm{NO}_{2}$ (Richter et al., 2005) and HCHO (Wittrock et al., 2006). In contrast to the aircraft measurements, these data give the integrated tropospheric column without vertical profile information and have a spatial resolution of the order of $30 \times 60 \mathrm{~km}^{2}$ for individual pixels. In Fig. 8, the tropospheric $\mathrm{NO}_{2}$ and $\mathrm{HCHO}$ fields from SCIAMACHY averaged over all data from July and August 2006 are shown.

The $\mathrm{NO}_{2}$ distribution is characterised by high values over regions of intense biomass burning and anthropogenic emissions and low values over desert and ocean. In the Sahel region, $\mathrm{NO}_{2}$ is slightly elevated probably as result of soil $\mathrm{NO}_{\mathrm{x}}$ 
emissions (also observed by the aircraft; Stewart et al., 2008) with no sharp gradient with latitude before about $18^{\circ} \mathrm{N}$. Interestingly, $\mathrm{NO}_{2}$ values over the ocean close to the coast are also elevated, and backward trajectories indicate that this is a result of transport of biomass burning affected airmasses from central Africa. No vertical information is available from the measurements but as the distances involved are rather large, transport must have taken place at higher altitudes where the $\mathrm{NO}_{\mathrm{x}}$ lifetime is larger.

Formaldehyde as an indicator of VOC chemistry is shown in the lower panel of Fig. 8. Its main sources are biogenic isoprene and biomass burning. Consequently, high values are observed over the region with fires and also over the densely vegetated part of the AMMA region. Some indication of transport from the biomass burning region can also be seen in the HCHO map, but to a much smaller degree than in the $\mathrm{NO}_{2}$. In spite of the general similarities between the $\mathrm{NO}_{2}$ and $\mathrm{HCHO}$ distributions, several important differences exist. Firstly, no anthropogenic (non-biomass burning) signals can be discerned in the region shown. Secondly, the $\mathrm{HCHO}$ maximum attributed to biomass burning is shifted to the north, indicating secondary production and contributions from biogenic emissions. And lastly, as no soil emissions are expected for $\mathrm{HCHO}$, the drop off in the AMMA region is more to the south than for $\mathrm{NO}_{2}$ with generally larger values and some hot spots south of $10^{\circ} \mathrm{N}$ and low values north of $15^{\circ} \mathrm{N}$.

As satellite measurements are all taken in relatively cloud free situations, the averages shown have a clear sky bias. Also, for comparison with the in-situ data discussed in the following sections, the integrated nature of the remote sensing has to be taken into account as well as the fact that $\mathrm{NO}_{2}$ is measured, not $\mathrm{NO}_{\mathrm{x}}$.

\subsection{Tropospheric profiles of ozone}

Figure 9 shows the average vertical profile of ozone concentrations measured on all aircraft. Rather than simply exhibiting an increase from the surface to the stratosphere, the profile is " $\mathrm{S}$ " shaped with a maximum in the median at around $400 \mathrm{hPa}$ and a minimum at around $250 \mathrm{hPa}$. This is typical of that seen elsewhere in the tropics where the minimum at $250 \mathrm{hPa}$ can be explained by the detrainment of ozone poor air that has been convectively lifted from lower altitudes (Folkins et al., 2002). Note that the maximum in the outlier concentrations ( $>99$ percentiles) at $650 \mathrm{hPa}$ is associated with the biomass burning plumes in the south of the region (see below and Fig. 10a).

Figure 10 illustrates how the vertical profile changes with latitude. At $6^{\circ} \mathrm{N}$ the " $\mathrm{S}$ " shaped profile is exaggerated with a maximum and large variability at $650 \mathrm{hPa}$ due to some air masses having been influenced by biomass burning emissions. Although there is a minimum in the median at $350 \mathrm{hPa}$ it is not clear if this is generated by the enhanced ozone concentrations below resulting from the biomass burning or due

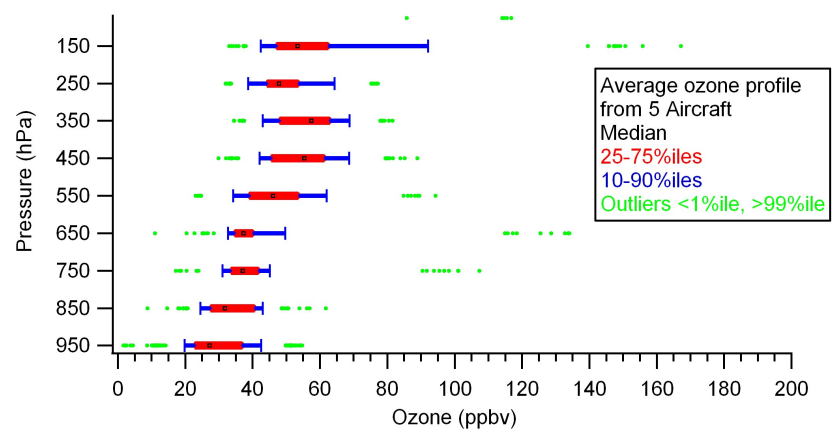

Fig. 9. Average vertical profile of ozone concentrations in bins of $100 \mathrm{hPa}$ of atmospheric pressure based on 1-minute data from the BAe-146, the DLR Falcon, the French Falcon, French ATR and the M55 between 20 July and 21 August 2006. The black marker is the median, the red box the range of the 25 to 75 percentiles, the blue whiskers the range of the 10 to 90 percentiles and the green points outliers less than the 1 percentile and greater than the 99 percentile. Note that the $\mathrm{x}$ - axis is limited to $200 \mathrm{ppbv}$ to show the variation of ozone in the troposphere. Ozone concentrations in the top layer are limited to data between 100 and $50 \mathrm{hPa}$ bin and exceed $200 \mathrm{ppbv}$.

to low concentrations of ozone convectively lifted to this altitude. At $10^{\circ} \mathrm{N}$ there is again no obvious sign of detrainment of convectively lifted ozone-poor air at $250 \mathrm{hPa}$. Instead of an " $\mathrm{S}$ " shape profile, the ozone concentrations increase from the surface to $550 \mathrm{hPa}$ where they remain reasonably constant up to $250 \mathrm{hPa}$, before increasing into the stratosphere. At $13^{\circ} \mathrm{N}$ the "S" shape profile is apparent with clear minima at the surface and at $250 \mathrm{hPa}$. At $16^{\circ} \mathrm{N}$ there is also an " $\mathrm{S}$ " shape profile with the minimum at $250 \mathrm{hPa}$, although the surface concentrations are greater than further to the south such that up to $750 \mathrm{hPa}$ the ozone concentrations are fairly similar, if anything decreasing with altitude.

This change in vertical profile with latitude suggests that the maximum in the convective uplift of ozone poor air is around $12-14^{\circ} \mathrm{N}$. This is slightly further north than the location of the inter-tropical convergence zone (ITCZ) which was centred around $10-12^{\circ} \mathrm{N}$ as indicated by the outgoing longwave radiation (OLR) for July and August 2006 (Janicot et al., 2008). It should be noted that some flights were designed specifically to target high altitude outflow from MCSs. This may therefore have biased the average profiles and latitudinal location of the maximum effect of this convective uplift.

Figure 11a shows the general profile behaviour of tropospheric ozone concentrations recorded by ozone sondes launched from Cotonou $\left(6^{\circ} \mathrm{N}\right)$ between 21 July and $22 \mathrm{Au}-$ gust. Concentrations from 9 individual soundings have been averaged into bins $100 \mathrm{hPa}$ thick as for the aircraft data presented in Fig. 10. Further details on these soundings data can be found in Thouret et al. (2009). In general, the composite profile from aircraft data at $6^{\circ} \mathrm{N}$ (Fig. 10a) and the averaged profile from the soundings highlight the same tropospheric behaviour described above as an "S" shape (i.e. low 
a)
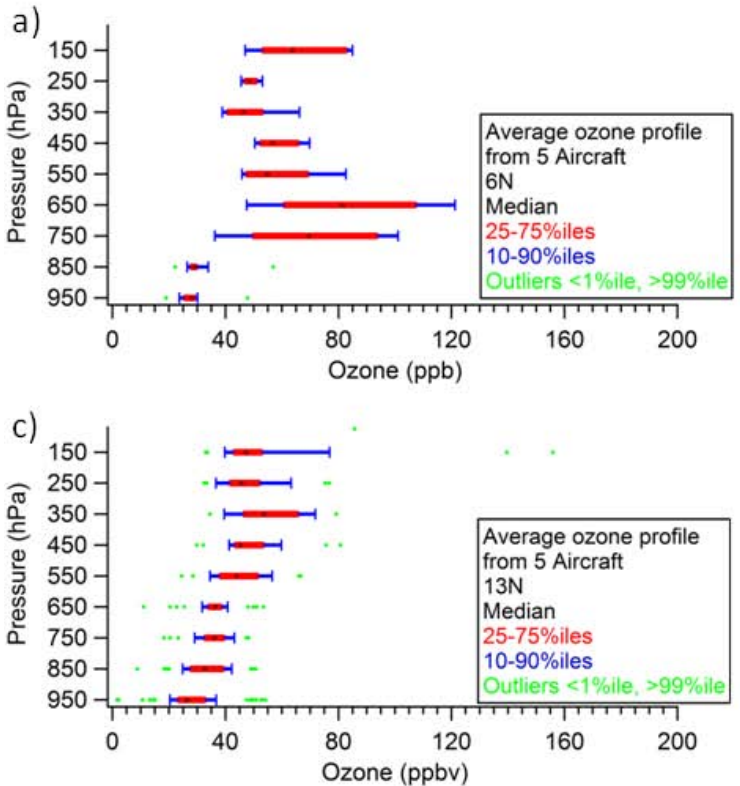
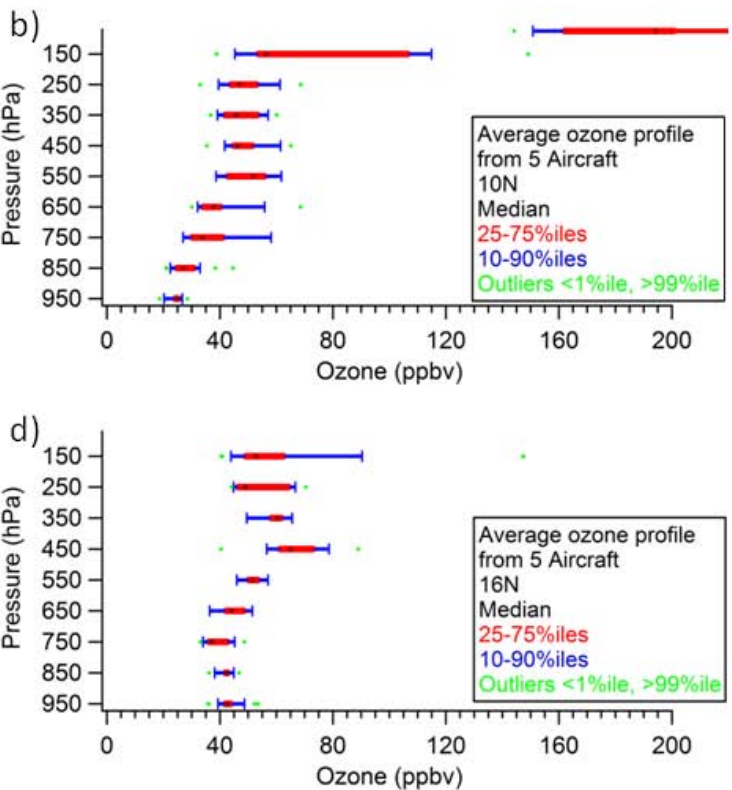

Fig. 10. Average vertical profiles of ozone concentrations in bins of $100 \mathrm{hPa}$ of atmospheric pressure at (a) $6^{\circ} \mathrm{N}$, (b) $10^{\circ} \mathrm{N}$, (c) $13^{\circ} \mathrm{N}$, and (d) $16^{\circ} \mathrm{N}$ based on 1-min data from the BAe-146, the DLR Falcon, the French Falcon and the M55 between 20 July and 21 August. The black marker is the median, the red box the range of the 25 to 75 percentiles, the blue whiskers the range of the 10 to 90 percentiles and the green points outliers less than the 1 percentile and greater than the 99 percentile. Ozone concentrations in the top layer are limited to data between 100 and $50 \mathrm{hPa}$ bin and exceed $200 \mathrm{ppbv}$.

surface concentrations, high ozone between 800 and $400 \mathrm{hPa}$, lower ozone around $250 \mathrm{hPa}$ and higher ozone in the UT by $100 \mathrm{hPa}$ ).

Both data sets exhibit high to very high ozone concentrations in layers between 800 and $400 \mathrm{hPa}$. This highlights the seasonal characteristic called "intrusions of biomass burning products from the southern hemisphere". As firstly revealed by the MOZAIC data recorded over Lagos and Abidjan (Sauvage et al., 2007; Sauvage et al., 2005), these high ozone concentrations go along with high $\mathrm{CO}$ values as well as other biomass burning tracers like acetonitrile (Fig. 7b). Consistent with the MOPITT CO data discussed above, Thouret et al. (2009) found by comparing the ozone sondes from Cotonou during AMMA with vertical profiles obtained by MOZAIC in other years, that these southern intrusions of biomass burning were particularly frequent in 2006 compared to other wet seasons.

In the upper troposphere, above $400 \mathrm{hPa}$, data from the soundings show higher concentrations with a median value close to $70 \mathrm{ppbv}$ between 400 and $200 \mathrm{hPa}$ and close to $85 \mathrm{ppbv}$ between 100 and $200 \mathrm{hPa}$ while the aircraft data exhibit around $20 \mathrm{ppbv}$ less. This may reflect the differences in the measurement techniques (Thouret et al., 2009) and in sampling strategies. The soundings were launched on predefined days irrespective of the conditions, but some flights were designed specifically to target high altitude outflow from MCSs. This may therefore have biased the average profiles and latitudinal location of the maximum effect of this convective uplift. For example a siginifcant ozone concentration difference (20-30 ppbv) is seen at $250 \mathrm{hPa}$ for the F-F20 flights around MCS and during the dry spells (Ancellet et al., 2009).

Figure $11 \mathrm{~b}$ shows the average profile for 29 ozone sondes that were released from Niamey $(13 \mathrm{~N})$ between 26 July and 25 August. Although the concentrations are similar to those observed by the aircraft near the surface (Fig. 10c), like the Cotonou sondes the Niamey ozone sonde data gives higher concentrations in the UT than the aircraft data. This might be the different measurement technique and sampling strategy. For Cotonou the ozone sondes were launched on prescribed days regardless of conditions and for Niamey the strategy was to smoothly cover the campaign with ozone soundings, whereas the aircraft flights were for specific missions and many of those in the UT were sampling around MCSs. No remarkable difference can be seen in the ozone data from ozone sondes that were launched to target convective systems and in fact one profile which diverges dramatically from the rest does not have any noticeably different history. It was a clear sky observation on 1 August 2006 early afternoon.

The M55 observing strategy was directed partly to sample the direct effects of MCSs on the UTLS and partly to characterize the UTLS in as nearly an unperturbed state as possible, i.e. far from MCS events (Cairo et al., 2010). The flight hours were nearly evenly distributed across these two goals. Following an analysis of air mass origins in the TTL (Law 

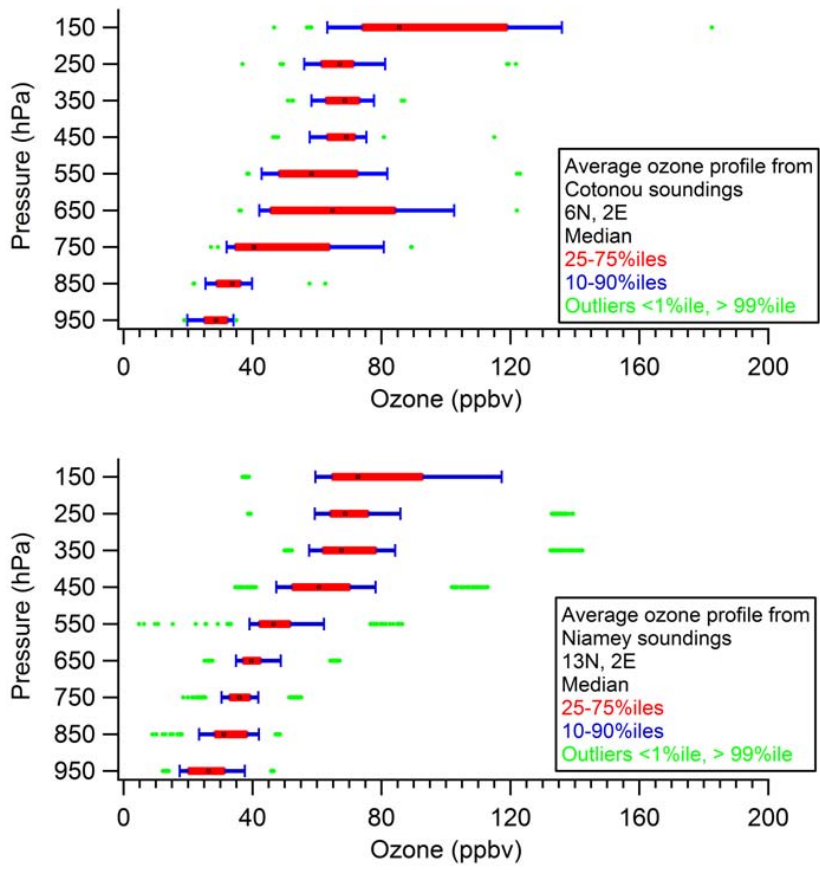

Fig. 11. Average ozone profiles based on (top) 9 soundings from Cotonou $\left(6^{\circ} \mathrm{N}, 2^{\circ} \mathrm{E}\right)$ launched at 10:00 or 11:00 a.m. local time between 21 July and 22 August 2006 and (bottom) 29 soundings from Niamey $\left(13^{\circ} \mathrm{N} 2^{\circ} \mathrm{E}\right)$ between 26 July and 25 August 2006. The black marker is the median, the red box the range of the 25 to 75 percentiles, the blue whiskers the range of the 10 to 90 percentiles and the green markers are less than the 1 percentile and greater than the 99 percentile.

et al., 2010), the M55 flights appear to be reasonably representative of air masses impacting these altitudes over West Africa. Model aided analysis confirms the presence of direct injection up to the tropical tropopause by intense convective systems and indicates that composition is dependent on the residence time in the TTL after convective uplift (Fierli et al., 2010).

Observations of coupled variations of total peroxy radicals with NO and non-methane hydrocarbons (NMHC), including isoprene, made on board the D-F20 and F-F20 in some of regions of convective outflow indicate uplift of radical and $\mathrm{O}_{3}$ precursors coincident with either uplift of $\mathrm{NO}$ or an emission of NO from lightning (Andres-Hernandez et al., 2009; Bechara et al., 2009). Significant net $\mathrm{O}_{3}$ production rates of around $1 \mathrm{ppbv} / \mathrm{h}$ have been calculated from measurements made in this outflow. Backward trajectories have also been overlaid on Meteosat Second Generation images to identify convectively influenced flight segments followed by forward photochemical modelling, initialised with data, to estimate net $\mathrm{O}_{3}$ production in these air masses. This shows that not only is $\mathrm{O}_{3}$ poor air lifted from the lower troposphere to the UT in these convective systems, but that this is counteracted to some degree by the uplift and emission of $\mathrm{O}_{3}$ pre- cursors. In some cases the precursors observed in the UT originated from biomass burning in the southern hemisphere over Central Africa and have been calculated to contribute to continued net $\mathrm{O}_{3}$ production for several days as the air was transported out over the ocean (Real et al., 2010), possibly contributing to the $\mathrm{O}_{3}$ maxima previously identified over the southern Atlantic (Weller et al., 1996; Thompson et al., 1996; Jenkins and Ryu, 2004a, b). The role of convection and $\mathrm{NO}_{\mathrm{x}}$ from lightning on the composition of the UT over W. Africa has been further examined in a study using 4 global chemical transport models (Barret et al., 2010), which showed that important differences between the UT CO and ozone distributions simulated by each of the models could be explained by differences in the convective transport parameterizations and, more particularly, the altitude reached by convective updrafts. Model sensitivity studies clearly indicated that the $\mathrm{CO}$ maxima and the elevated ozone concentrations south of the equator are due to convective uplift of air masses impacted by Southern African biomass burning, in agreement with previous studies. Moreover, during the West African Monsoon, $\mathrm{NO}_{\mathrm{x}}$ from lightning over W. Africa is calculated to be responsible for 10-20 ppbv enhancements in UT ozone over the tropical Atlantic.

\subsection{Biomass burning}

As already mentioned above, elevated concentrations ( $>100 \mathrm{ppbv}$ ) of ozone were observed in the southern midtroposphere of the region sampled by the aircraft during AMMA. Ozone vertical profiles collected through the MOZAIC program between 1997 and 2003 over Lagos and Abidjan, Ivory Coast, during July and August, a similar time of year to the AMMA flights, also exhibit elevated concentrations around $650 \mathrm{hPa}$ (Sauvage et al., 2005). This feature in the MOZAIC data was not systematic, but rather a variable one. Similarly the range in the percentiles at 750 and $650 \mathrm{hPa}$ at $6^{\circ} \mathrm{N}$ (Fig. 10) illustrate that this was a variable feature in the AMMA aircraft data.

June to August is the wet season in West Africa when biomass burning is at a minimum. Sauvage et al (2005), however, attributed the enhanced ozone observed in the MOZAIC data to biomass burning in the southern hemisphere by using trajectory analysis and fire count data. The acetonitrile data, collected during AMMA on the BAe-146 aircraft (Murphy et al., 2010), unequivocally confirms that biomass burning had influenced these air masses. During SOP2, observations of the size-resolved chemical composition of individual aerosol particles by transmission and scanning electron microscopy coupled with energy dispersive X-ray analysis (Fig. 12) show the presence of submicron biomass burning aerosol particles even in the area around Niamey. Biomass burning particles have been identified as $\mathrm{K}$ (in addition to $\mathrm{S}$ ) enriched particles composed mainly of $\mathrm{C}$ (and $\mathrm{O}$ ), whereas particles showing a fractal or chain like aggregate structure and giving only the $\mathrm{X}$-ray peak of $\mathrm{C}$ have been classified as elemental carbon. A 


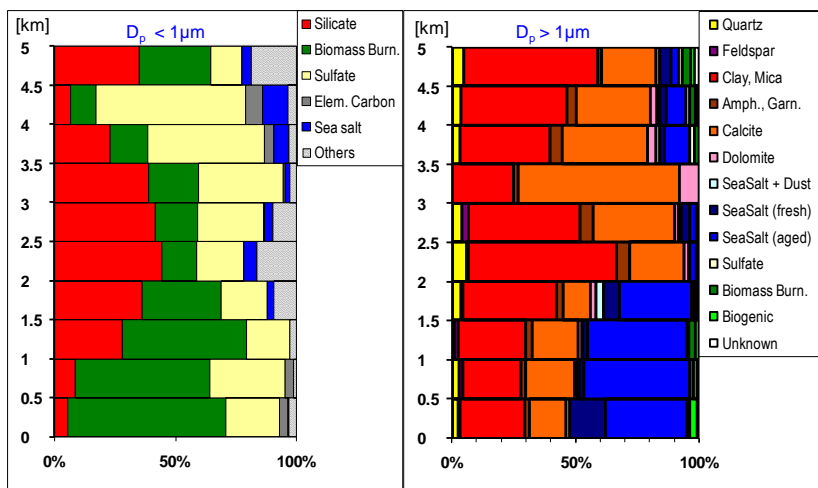

Fig. 12. Various types of aerosol particles identified by individual particle analysis in the submicron and supermicron sizes, and their relative abundance averaged over all ATR-42 flights during SOP2a2.

detailed discussion of the particle identification procedure is presented in Matsuki et al. (2010a).

Further, using a particle dispersion model coupled with daily active fire products from MODIS, Mari et al. (2008) identifies these air masses to have been impacted by biomass burning which took place in southern Africa and subsequently transported into West Africa in the easterly flow associated with the southern AEJ (S-AEJ). The variability in the ozone concentrations reflects the variability in the occurrence of such transport events which is dependent on whether the S-AEJ is active or not. Real et al. (2010) also examined in further detail a particular event sampled by the M55 at $13 \mathrm{~km}$ over southern West Africa. It appears that northerly transport of biomass burning emissions into central Africa followed by convective uplift and westward transport by the TEJ was the main transport mechanism. Williams et al. (2010) show that the ability of chemistry transport models to simulate these biomass burning transport events is highly dependent on the meteorological analysis data that is used to drive the model.

The modification of the aerosol vertical profile induced by such events is illustrated in Fig. 13 by the comparison of the vertical profiles of the aerosol scattering coefficient measured by the AVIRAD aerosol sampling system onboard the ATR-42 during two different flights over the Gulf of Guinea in the $3-4^{\circ} \mathrm{N}$ area (longitude $2.5^{\circ} \mathrm{E}$ ), the first conducted during SOP 1a1 and the second during SOP 2a1 (Formenti et al., 2010). The spectral dependence of scattering indicates that the aerosol size distribution is dominated by particles in the accumulation mode. Flight V024 (14 June) represents background marine conditions in the area, with low scattering values in the boundary layer $\left(\sim 50 \mathrm{Mm}^{-1}\right.$; $1 \mathrm{Mm}^{-1}=10^{-6} \mathrm{~m}^{-1}$ ), decreasing to zero above. Transport on biomass burning on 4 July (flight V030 of the F ATR42) results in the appearance of an elevated layer extending up to $3 \mathrm{~km}$ and showing values up to $100 \mathrm{Mm}^{-1}$ at $450 \mathrm{~nm}$, whereas the aerosol vertical distribution in the boundary

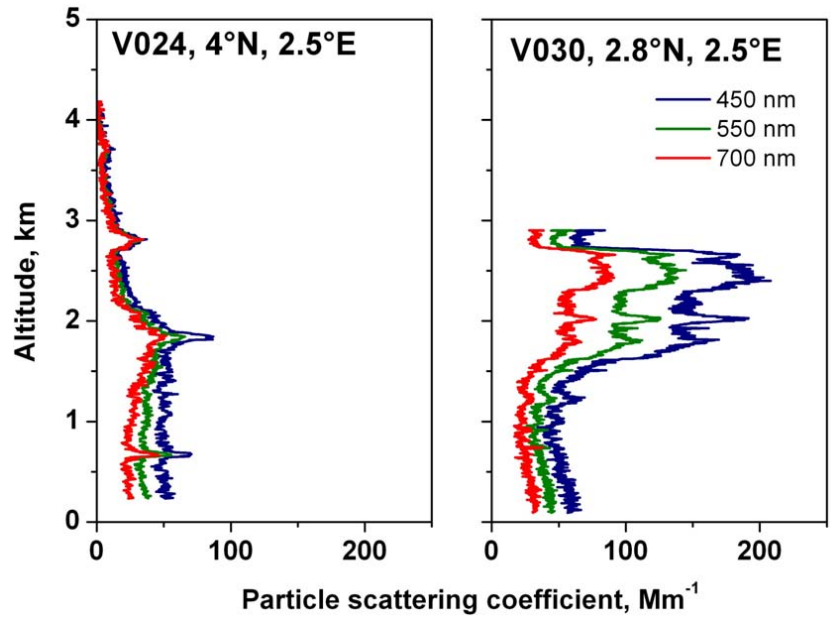

Fig. 13. Vertical profiles of the aerosol scattering coefficient measured during flights V024 of SOP 1a1 and V030 of SOP 2a1 at 450 (blue line), 550 (green line), and $700 \mathrm{~nm}$ (red line) by the ATR-42.

layer remains unperturbed. This additional layer contributes 0.15 to the column scattering optical depth (obtained by integrating the scattering profile over the depth of the layer), which is comparable to the annually-averaged median total aerosol extinction optical depth estimated by the AEROCOM modelling exercise (Textor et al., 2006), especially when considering that the absorption optical depth (not accounted for by the aircraft data) should be significant. Further, the aircraft sounding was topped at $3 \mathrm{~km}$, so it is not possible to conclude anything about the presence of a secondary layer in the upper troposphere, as evident in some of the ozone profiles analysed by Thouret et al. (2009), which could also contribute significantly to the columnar light extinction.

Although intrusions of such air during the wet season had been observed before (Sauvage et al., 2005), it was largely expected that biogenic emissions would dominate at this time of year. Despite this, one of the main features of the AMMA campaign was the large impact of biomass burning in the southern hemisphere on the composition of the troposphere over West Africa. However analysis of several years of vertical ozone profiles (Thouret et al., 2009) and the CO data from MOPPIT (see above) suggests that the impact of the biomass burning was in fact greater in the wet season of 2006 than in other recent years.

\subsection{Land surface impact}

For ozone, the most noticeable gradient in the lower troposphere is a latitudinal one (Fig. 3). Focussing on data at pressures greater than $900 \mathrm{hPa}$, average ozone concentrations decline from 30 to $20 \mathrm{ppbv}$ from over the ocean $\left(5^{\circ} \mathrm{N}\right)$ inland to around $11^{\circ} \mathrm{N}$ (Fig. 14a). There is then a sharp increase to over $40 \mathrm{ppbv}$ at $15^{\circ} \mathrm{N}$, before declining again further to the north. The ITD was located closer to $20^{\circ} \mathrm{N}$ (Janicot et 

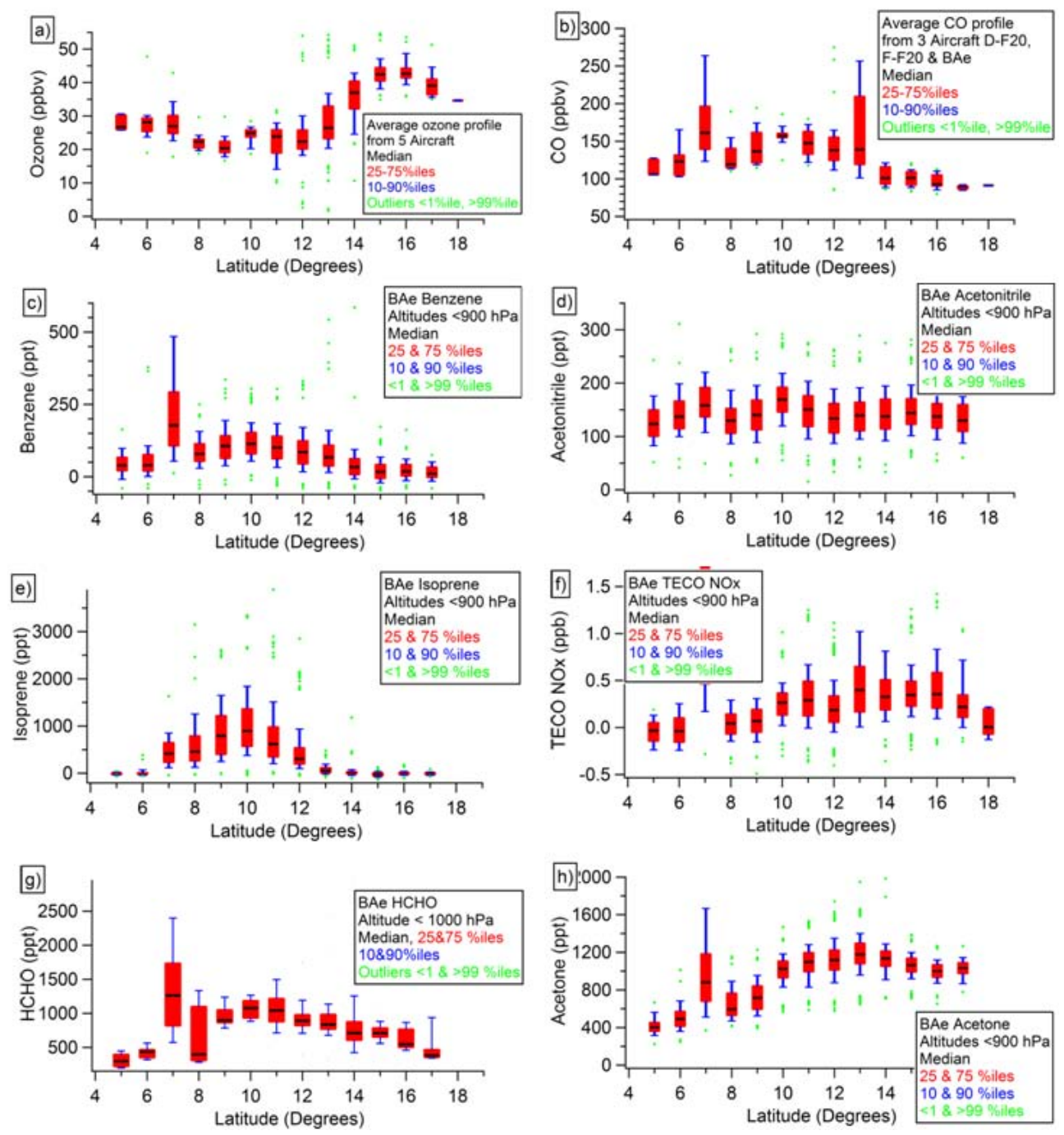

Fig. 14. Average latitudinal profile at altitudes below $900 \mathrm{hPa}$ atmospheric pressure between 20 July and 21 August. The black marker is the median, the red box the range of the 25 to 75 percentiles, the blue whiskers the range of the 10 to 90 percentiles and the green points outliers less than the 1 percentile and greater than the 99 percentile. (a) ozone (all aircraft), (b) CO (D-F20, F-F20, BAe only), (c) benzene (BAe only), (d) acetonitrile (BAe only), (e) isoprene (BAe only), (f) $\mathrm{NO}_{\mathrm{x}}$ (BAe only), (g) HCHO (BAe only), and (h) acetone (BAe only).

al., 2008) so the reason for the pattern in the $\mathrm{O}_{3}$ is unlikely to simply be a function of the south westerly monsoon air being lower in $\mathrm{O}_{3}$ than the north easterly Harmattan. There is, however, a strong vegetation gradient around $12-13^{\circ} \mathrm{N}$ (Janicot et al., 2008), with substantial tree cover to the south and scrubland and bare soil to the north. A similar pattern for $\mathrm{O}_{3}$ has been observed at surface IDAF (IGAC-DEBITSAFRICA) sites during the wet season, which shows mixing ratios to be around $10 \mathrm{ppbv}$ higher over dry savannas in the north compared to wet savannas to the south (Adon et al., 2010).

The changing vegetation and land-use will not only affect emissions of relevant trace gases but also deposition. The lower $\mathrm{O}_{3}$ concentrations between 6 and $12^{\circ} \mathrm{N}$ are likely to be at least partly due to rapid deposition to trees (Cros et al., 2000). The fact that ozone decreases in concentration from the coast inland over the trees, in the direction of the predominant monsoon flow, suggests that the sink (chemical and depositional) is greater than the source. $\mathrm{CO}$ concentrations (Fig. 14b) are generally anticorrelated with ozone, the highest values being between 9 and $11^{\circ} \mathrm{N}$. The exceptions are at $7^{\circ} \mathrm{N}$, which is largely due to emissions from the coastal cities such as Lagos (Hopkins et al., 2009) and Cotonou, and at $13^{\circ} \mathrm{N}$, which coincides with the aircraft bases of Niamey and Ouagadougou. Interestingly the predominantly anthropogenic tracer, benzene, shows a similar pattern to $\mathrm{CO}$. Acetonitrile, the biomass burning tracer, shows no latitudinal gradient at these altitudes (Fig. 14d) suggesting little contribution from anthropogenic sources. Isoprene (Fig. 14e), a biogenic species with a lifetime of only 
a few hours, had enhanced mixing ratios across about $6^{\circ}$ of latitude $(\sim 700 \mathrm{~km})$, showing its widespread impact on the composition of the boundary layer (Murphy et al., 2010). Its short atmospheric lifetime means that it is largely confined to locations close to its source, in this case the forested areas. Ferreira et al. (2010) confirm that this concentration distribution is largely consistent with the emission distribution predicted by MEGAN (Model of Emissions of Gases and Aerosols from Nature (Guenther et al., 2006)).

$\mathrm{NO}_{\mathrm{x}}$ (Fig. 14g), like $\mathrm{CO}$ and benzene is highest around the cities, but unlike them it does not decrease from $10-11^{\circ} \mathrm{N}$ northwards, but remains high until around $17^{\circ} \mathrm{N}$ (similar to the column $\mathrm{NO}_{2}$ observed by satellite). This is most probably due to emissions of $\mathrm{NO}_{\mathrm{x}}$ from recently wetted bare soil in the north (Delon et al., 2008; Saunois et al., 2009; Stewart et al., 2008). Assuming a $\mathrm{NO}_{\mathrm{x}}$ limited atmosphere, this latitudinal gradient in $\mathrm{NO}_{\mathrm{x}}$ concentration should reflect the latitudinal gradient in photochemical production of ozone, which is consistent with the latitudinal gradient of ozone and enhanced deposition over the trees. Stewart et al observed enhanced $\mathrm{O}_{3}$ along with enhanced $\mathrm{NO}$ over recently wetted soils supporting the idea of photochemical production of $\mathrm{O}_{3}$ from soil $\mathrm{NO}_{\mathrm{x}}$ emissions. The modelling study by Saunois et al. (2009) confirms the hypothesis that the ozone latitudinal gradient in the lower troposphere over W. Africa is a result of the rapid deposition to trees in the south and enhanced $\mathrm{NO}_{\mathrm{x}}$ from bare soils in the north.

HCHO has a lifetime of a few hours and is often used as a marker of isoprene emissions (Shim et al., 2005). Although its concentration profile peaks at around $10-11^{\circ} \mathrm{N}$ its concentration does not drop off so rapidly to the north (Fig. 14h). This low altitude latitudinal gradient is similar to that of the column observed by SCIAMACHY, although perhaps declining less rapidly northwards. Acetone, which has a lifetime of several days, peaks at around $13^{\circ} \mathrm{N}$ and remains reasonably high over the bare soils to the northerly extent of the aircraft observations at $18^{\circ} \mathrm{N}$ (Fig. 14f). Although HCHO and acetone can both have primary sources they are also produced via oxidation of carbon compounds. The latitudinal profiles of these oxygenated VOCs, suggest a combination of northward advection and in-situ oxidation chemistry in this northern region. The Saunois et al. (2009) modelling study suggests that partially oxidised VOCs, produced from isoprene oxidation in the south, may, following northwards advection, also contribute to the enhanced ozone in the north.

\subsection{Mobilisation, transport and properties of mineral dust}

Models and observations agree in indicating that in the wet season mineral dust is the dominant aerosol type over western Africa, both in terms of mass and light extinction (Textor et al., 2007; Rajot et al., 2008; Marticorena et al., 2010). Mineral particles are ubiquitous in the vertical distribution of the supermicron fraction, with maximum concentrations being found above $2 \mathrm{~km}$ (Fig. 12, Matsuki et al., 2010b), even during SOP 2a2 in the mature Monsoon period, when precipitation is expected to reduce emission and enhance deposition.

During AMMA SOP 1a and SOP 2a1, IOPs 1.1 and 1.2 yielded data on mineral dust. Studies under IOP 1.1 (Table 3) used a rather novel combination of airborne lidars and dropsondes to investigate dust mobilisation and transport over West Africa. In these studies, the structure of the aerosol fields was documented at the regional scale using the airborne lidar LEANDRE 2 (Bruneau et al., 2001) with resolutions of $15 \mathrm{~m}$ in the vertical and $1.5 \mathrm{~km}$ in the horizontal. LEANDRE-derived reflectivity at $730 \mathrm{~nm}$ is mostly sensitive to aerosols with radii ranging from 0.1 to $5 \mu \mathrm{m}$, where a large fraction of the size distribution of dust aerosols is concentrated. Furthermore, reflectivity is sensitive to aerosol optical properties and concentration, as well as relative humidity in the case of hygroscopic aerosols, such as those generally present in the monsoon layer (e.g. Crumeyrolle et al., 2008). On the other hand, over the African continent and close to the sources, desert dust particles are generally considered to be hydrophobic (Fan et al., 2004). Therefore, reflectivity associated with desert dust is generally not expected to be sensitive to relative humidity fluctuations, and can be used as a proxy for dust concentration (Flamant et al., 2007; Flamant et al., 2009b; Flamant et al., 2009a). Observations within IOP 1.2 (Table 3 ) were mostly dedicated to the situ characterization of the physico-chemical and optical properties of mineral dust emitted by MCSs (Formenti et al., 2010). The IOP type 1.2 dedicated to this science issue consisted of two coupled flights, one before and one after the passage of an MCS, and in coordination with observations at the ground supersite of Banizoumbou in Niger. Due to the poor predictability, in practical terms encompassing an MCS was very complicated, and could be achieved only on a couple of occasions. However, almost all the flights included vertical profiles and straight and level runs sampling at various heights within the aerosol layer and therefore provided a large extent of data of the physico-chemical properties of mineral dust transported over Western Africa. Within IOP 1.2, Crumeyrolle et al (2008) showed that the passage of MCS involve significant change in aerosol chemical properties. As a result, after the MCS passage, the contribution of sulphate, nitrate and chloride to the total aerosol mass is higher which increase the hygroscopic properties of aerosols.

Bou Karam et al., (2008) have identified a new mechanism for dust emission over the Sahel during the summer, in which highly turbulent winds at the leading edge of the monsoon nocturnal flow in the ITD region generate dust uplifting. Airborne lidar data also contributed to the validation of model-derived quantification of dust emission in the ITD region (Bou Karam et al., 2009). Using the three-dimensional mesoscale numerical model MesoNH, Bou Karam et al. (2009) have shown that the daily mean 


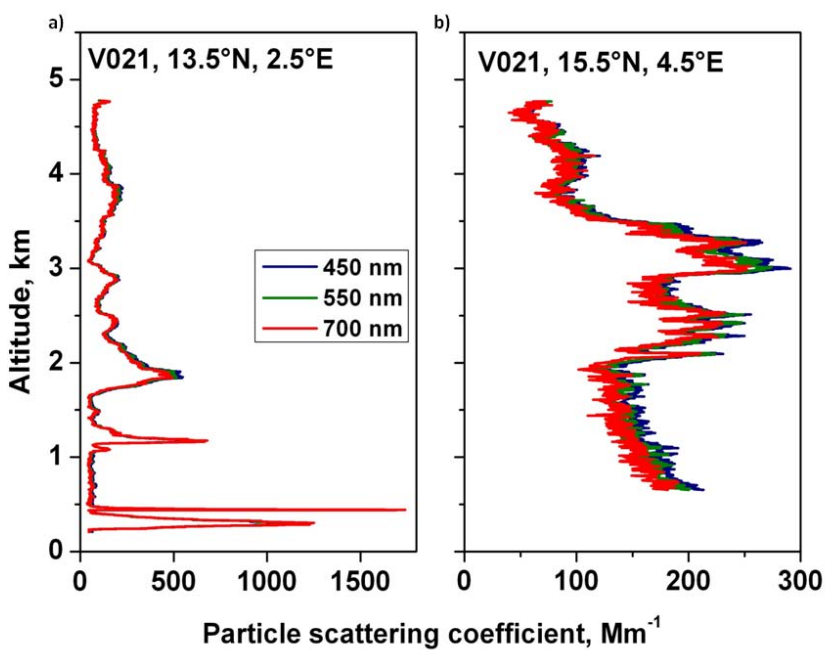

Fig. 15. Vertical profiles of the aerosol scattering coefficient of mineral dust as measured during flight V021 of SOP 1a1 at 450 (blue line), 550 (green line), and $700 \mathrm{~nm}$ (red line) by the ATR-42.

values of dust load related to the strong winds on both sides of the ITD over Niger and Mali could reach $2 \mathrm{Tg}$ on some of the days in July 2006. Their study suggests that emissions driven by strong surface winds occurring on both sides of the ITD while it lies across the Sahel may contribute significantly to the total dust load over West and North Africa observed annually.

Airborne lidar measurements have highlighted the fact that the Sahelian planetary boundary layer (PBL) exhibits a twolayer structure, with a well-mixed convective boundary layer, topped by a layer of low static stability up to around 5$6 \mathrm{~km}$ above mean sea level, and that away from source regions, long-range transport of desert dust mostly occurred within the elevated part of the Sahelian PBL (Flamant et al., 2007, 2009a; Marsham et al., 2008). These measurements also unambiguously show that injection of dust to altitudes favourable for long-range transport (i.e. in the upper Sahelian PBL) can occur behind the leading edge of mesoscale convective system cold-pools, particularly at the beginning of the monsoon season, before the growing vegetation rapidly inhibits local dust emission (Flamant et al., 2007, 2009a). Examples of the vertical distribution of mineral dust are shown in Fig. 15 in terms of the vertical profiles of the spectral aerosol scattering coefficient observed during two soundings on one flight conducted on June 11: Fig. 15a shows the vertical profile encountered over Banizoumbou $\left(13.5^{\circ} \mathrm{N}, 2.5^{\circ} \mathrm{E}\right)$, whereas Fig. $15 \mathrm{~b}$ shows the vertical profiles encountered farther north over northern Niger $\left(15.5^{\circ} \mathrm{N}, 4.5^{\circ} \mathrm{E}\right)$. The contrast between the two situations is striking: the vertical profile over the north of Niger corresponds to the classic situation expected for dust transport in the upper PBL across West Africa, associated with the AEJ, within the so-called Saharan Air Layer (SAL) (Flamant et al., 2009b; Karyampudi et al., 1999). This observation is clearly confirmed also from all measurements of the D-F20: Aerosol particle number concentrations in the accumulation mode size range (Fig. 16, right panel) as well as in the coarse mode (not shown) are characterized by enhanced values mainly between 2 and $5 \mathrm{~km}$ altitude, reflecting the persistent presence of dust within the AEJ over Burkina Faso during SOP 2a2. In this respect, Flamant et al. (2009c) have also shown that the dust load in the upper Sahelian PBL was also modulated by the propagation of African Easterly waves, with alternating high and low dust contents in the upper part of the Sahelian PBL associated with the northerly and southerly sectors of the AEWs, respectively.

A few hundreds of kilometres south, the aerosol vertical distribution over Banizoumbou is more stratified, showing various plumes of about $500 \mathrm{~m}$ depth even in the boundary layer, as a result of dust mobilisation at the edges of localised convection (Fig. 15a). The contrast between local production and synoptic transport at the hundreds of kilometres scale is supported by temporally-resolved satellite imagery (such as MSG), which also show that convective systems might mobilise dust over areas of the order of hundreds of kilometres (Crumeyrolle et al., 2008), and therefore needs to be represented by regional models. One should note the different intensity of the two episodes, the one observed over Banizoumbou giving rise to aerosol scattering up to five times higher than observed farther north. Furthermore, previous measurements in the Niger area have indicated that agricultural fields are the only source of significant dust emission fluxes (Bielders et al., 2001, 2002; Rajot, 2001; Bielders et al., 2004), therefore, mineral dust emitted by MCSs in the Sahel is of anthropogenic origin and must be accounted for when estimating the aerosol forcing on climate at the regional and global scales. Moreover, recent studies investigated the impact of vegetation heterogeneities on the dynamics within the planetary boundary layer (Garcia-Carreras et al., 2010; Taylor et al., 2007) and on the dust transport in the SAL (Crumeyrolle et al., 2010). Indeed, vegetation anomalies are associated with an increase of the top of the boundary layer which leads to entrainment of dusty air from the SAL to the boundary layer.

The chemical composition of dust emitted by MCSs from the Sahel was distinguished from that of dust transported from source regions in the Sahara due to its enrichment in iron, which is consistent with knowledge of the mineralogy of Sahelian soils, enriched by light-absorbing iron oxides (Claquin et al., 1999). Iron-enriched aerosols were found in the continental boundary layer below $1.5 \mathrm{~km}$ a few hours after the passage of a convective event and in the upper Sahelian PBL between 2 and $5 \mathrm{~km}$ behind the leading edge of mesoscale convective systems (Formenti et al., 2010). These aerosols should be more absorbing than those emitted from source regions in the Sahara, at least at UV-VIS wavelengths. The in situ scattering and absorption properties measured simultaneously to the composition tend to support this 

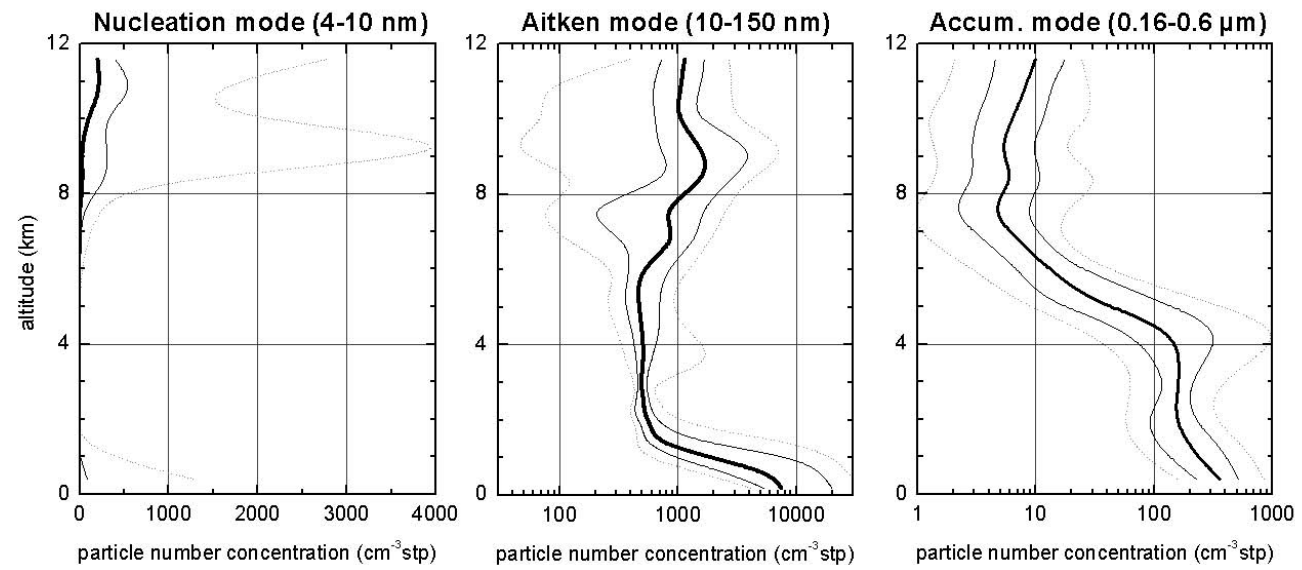

Fig. 16. Vertical distribution of aerosol number concentrations of nucleation mode (approx. 4-10 nm particle diameter; left panel), Aitken mode (approx. 10-150 nm particle diameter; middle panel), and accumulation mode (approx. 160-600 nm; right panel) over the Sahel region from D-F20 flights in August 2008. Only data between 7 and $20^{\circ}$ northern latitude and out of clouds are included. Number concentrations refer to standard conditions of $273 \mathrm{~K}$ and $1013 \mathrm{hPa}$. Statistics are calculated for 800 altitude bins and illustrated as follows: thick line: median; thin line: 25- and 75-percentile; dotted line: 10- and 90-percentile. The left panel does not include 10- and 25- percentile because not significantly different from zero for all altitudes.

conclusion (Formenti et al., 2010). In the coarse mode the number size distributions measured by optical counting for the Sahel and Sahara are consistent with those reported by Osborne et al. (2008) and McConnell et al. (2008) for Saharan mineral dust sampled in the dry season. The aircraft measured mass geometric mean diameter locates around $4 \mu \mathrm{m}$, close to one of the modal mean diameters observed by Rajot et al. (2008) for surface size distribution of mineral dust transported over the ground at the Banizoumbou supersite in Niger. These authors report that the mass distribution of locally emitted dust peaks around $8.7 \mu \mathrm{m}$. To date, the integration of the observations acquired within AMMA has not advanced to the point of providing new highlights of the dynamics of the dust size distribution during its atmospheric cycle. Crumeyrolle et al. (2010) have pointed out discrepancies between size distributions observed during a dust event in SOP1 and that expected from the Alfaro and Gomes (2001) model. The parametrisation of the dust size distribution in chemistry-transport models should be considered a futureresearch priority.

\subsection{Formation of biogenic secondary organic aerosol}

The UK BAe-146 extensively sampled the air in the monsoon region during SOP2a2. Many flights were conducted at low level within this layer above the densely vegetated region of the southern Sahel between the Gulf of Guinea and southern Niger. The high isoprene concentrations of 1-3 ppbv, observed at levels below $2 \mathrm{~km}$ throughout this region, have been shown to be a result of extensive biogenic emissions from the vegetation. Isoprene and monoterpenes have been shown to produce significant yields of secondary organic aerosol in chamber studies (e.g. Kroll et al., 2006). This implies that the high concentrations of isoprene observed from the aircraft observations and the elevated monoterpene concentrations observed by Saxton et al. (2007) at a ground based site in Benin during June 2006 could be significant sources of secondary organic aerosol (SOA) across the region.

Capes et al. (2009) investigated the extent of SOA in the region using a Quadrupole Aerodyne Aerosol Mass Spectrometer (Q-AMS). They have provided the first estimates of SOA across the West African Sahel and have shown that organic mass loadings vary between 0 and $2 \mu \mathrm{g} \mathrm{m}^{-3}$ with a median concentration of $1.07 \mu \mathrm{g} \mathrm{m}^{-3}$. Further when they use a simple approach based on product yields of methyl vinyl ketone (MVK), methacrolein (MACR) and SOA from chamber experiments and measurements of MVK and MACR to derive an expected SOA abundance, along with an SOA abundance derived from selected monoterpenes, they show that this approach under predicts SOA abundance by a factor of 4-15 compared to measured concentrations. This result is consistent with findings from measurements of organic aerosol mass loadings in more polluted continental environments throughout the mid-latitude northern hemisphere (Zhang et al., 2007), which show measured SOA abundance can be significantly higher than model predictions based on extrapolated chamber yield information (e.g. Volkamer et al., 2006). The under predictions of organic matter by these calculations and those in the mid latitudes are based on yields extrapolated from chamber data obtained at higher mass concentrations. However, Capes et al. show that more recent yield data obtained under atmospherically relevant mass concentrations (Shilling et al., 2008) gives much closer agreement with measurements than yields which have been extrapolated from chamber studies at higher mass concentrations. 
Capes et al. (2009) also compare their measurements with global model results for the region (e.g. (Chung and Seinfeld, 2002) and show that the concentrations are consistent within the large uncertainties associated with measurement and model outputs. However since these model results used the older yield rates this result points to further differences between global model estimates and measurements of SOA, most likely caused by use of incorrect BVOC emission rates.

\subsection{Aerosol nucleation in the upper troposphere}

One of the main objectives of the D-F20 flights in SOP 2a2 was to study the influence of mesoscale convective systems (MCSs) on the aerosol budget in the middle and upper troposphere over the West African continent. Measurements were taken during eight local flights from Ouagadougou as well as during the ferry flights from Germany to Burkina Faso and back (see Supplementary Information).

The aerosol instrumentation of the D-F20 consisted of a combination of a multi-channel condensation particle counter system, an optical particle counter, a differential mobility analyzer and a 3-wavelength particle absorption photometer, all connected to the near-isokinetic aerosol inlet of the D-F20 as well as two optical aerosol spectrometer probes mounted under the wings. With this payload the complete size distribution of the aerosol particles could be assessed. As this combination of instruments had a lower size cut of $4 \mathrm{~nm}$, it was possible to detect the presence of freshly formed ultrafine particles below $10 \mathrm{~nm}$ particle diameter.

Flights were performed in the close vicinity of active MCSs, in aged outflows of MCSs, and in background conditions with no apparent influence of active deep convection. Both tracer observations $\left(\mathrm{NO}, \mathrm{NO}_{\mathrm{y}}\right)$ as well as aerosol number concentration measurements consistently showed that the outflow region of deep convective systems is to be found above $8 \mathrm{~km}$ altitude and reaches up to at least the maximum flight altitude of the D-F20 Falcon of $12 \mathrm{~km}$.

Figure 16 presents the vertical distribution of nucleation, Aitken and accumulation mode particles over the Sahel as determined in August from the D-F20 flights. The vertical profile of Aitken mode particle number concentrations shows the important contribution of ground sources and local urban pollution of Ouagadougou, which is confined to the boundary layer (on average roughly below $2 \mathrm{~km}$ altitude). Aerosol concentrations are fairly low in the middle troposphere (between boundary layer and approx. $8 \mathrm{~km}$ altitude) and particle formation events are not observed at all in this altitude region. At altitudes above approximately $8 \mathrm{~km}$, the profile of the median Aitken mode particle concentration shows an increasing trend with altitude but the overall concentration variability in the upper troposphere is remarkably high. Very low concentrations were observed in general in the fresh outflow of active MCSs and are very likely caused by efficient wet removal of aerosol particles due to heavy precipitation inside the convective cells of the MCSs. This wet removal

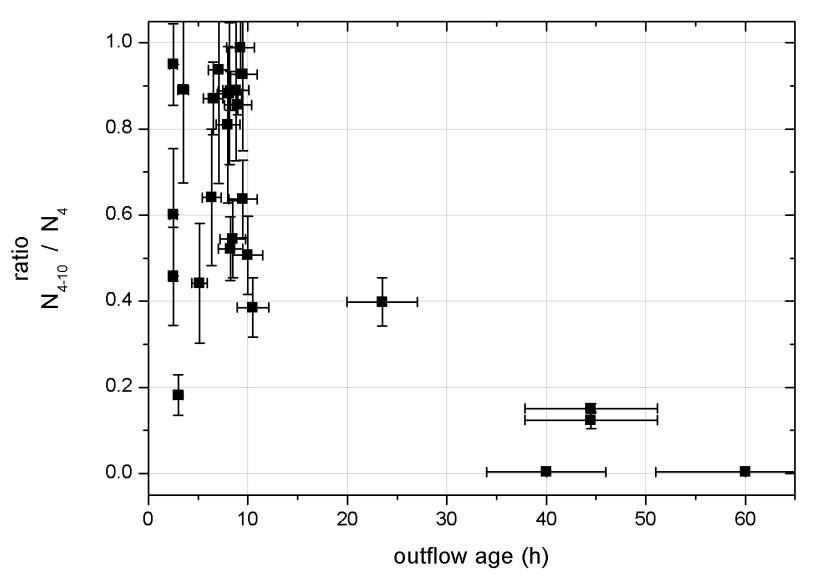

Fig. 17. Mean ratio of the number concentrations of nucleation mode particles (4-10 diameter range; $\mathrm{N}_{4-10}$ ) to the total number of particles $\left(>4 \mathrm{~nm} ; \mathrm{N}_{4}\right)$ measured in MCS outflow during 26 different cases with varying outflow age between 2.5 and $60 \mathrm{~h}$. Each case represents an average value calculated from typically a few hundred original data points sampled at $1 \mathrm{~Hz}$.

initially affects all particle size ranges as clearly shown by all measurements in the vicinity of MCSs.

The vertical distribution of nucleation mode particle concentrations reveals that significant and fairly strong particle formation events did occur for a considerable fraction of measurement time above $8 \mathrm{~km}$ (and only there). This is consistent with the fraction of observations exhibiting higher Aitken mode particle concentrations in the upper troposphere because it is in general to be expected that particle nucleation events are followed by further growth of particles into the Aitken mode.

Different flights provided measurements that span time scales of air mass age in the outflow of MCS systems from hours to a couple of days. The temporal evolution of properties of aerosols processed in deep convective systems and then released to the middle and upper tropical troposphere can be studied when all the flights are combined. Figure 17 shows the fraction of particles in the nucleation mode compared to the total particle number. The age of outflow air was estimated depending on the proximity of the storm: in the close vicinity of active MCS the time since passage of the coldest (i.e. highest and most active) point of the convection cell at the measurement location was determined from the lateral movement of the MCS using satellite (MSG) imagery. When the outflow age was greater than about 10 hours, the age was determined by trajectory analysis using the trajectory model LAGRANTO, the wind fields were provided by ECMWF analysis data with a spectral resolution of T319L91 in combination with MSG imagery. Figure 17 shows that new particle formation is observed in the outflow if the air processed by the convective system has aged for a few hours at least. In MCS outflow cases of one day age or more, however, particle nucleation events are no longer observed. 
During a particularly useful case study performed during the flight on 11 August the temporal evolution of the aerosol size distribution could be documented while flying inside the outflow of an MCS system over Burkina Faso towards the east, whilst moving away from the active MCS centre and thereby spanning increasing outflow age (i.e. increasing processing time). The series of measured size distributions (not shown here) show a rapid (within hours) shift of the size distribution from being initially nucleation mode dominated into Aitken mode dominated.

Without knowing the exact nature of the aerosol precursor gases being lifted up in the convective cells, the following steps in the evolution of aerosol properties after MCS passage appear to be consistent with the upper tropospheric observations during the AMMA monsoon season: (a) In fresh outflow (very close to the MCS) aerosol of all sizes is efficiently removed. (b) Ageing of some hours leads to new particle formation while pre-existing aerosol surface area is very low. (c) This is followed by an increase of particle concentration in the Aitken mode due to the growth of particles, while further nucleation does not appear to occur. The concentration of accumulation and coarse mode particles remains very low at this point. (d) Some tens of hours later, in aged outflow (and in general in upper tropospheric "background"), nucleation does not occur and aerosol concentrations recover. This latter observation is possibly due to lateral mixing, dry convection and long-range transport.

\section{Summary}

During June, July and August 2006 five research aircraft (BAe-146, F-F20, ATR-42, D-F20 and M55) made comprehensive measurements of aerosols and trace gases from the boundary layer to the lower stratosphere (around $50 \mathrm{hPa}$ ), from $2^{\circ} \mathrm{N}$ to $21^{\circ} \mathrm{N}$, and between $10^{\circ} \mathrm{W}$ and $7^{\circ} \mathrm{E}$. Wing-tipto wing-tip comparisons were performed between the BAe146 and 3 of the other aircraft (F-F20, ATR-42 and D-F20) which aided the compilation of single data sets for $\mathrm{O}_{3}$ and $\mathrm{CO}$ concentrations for the region.

Very little longitudinal variation was found in either $\mathrm{O}_{3}$ or $\mathrm{CO}$, but both showed strong vertical and latitudinal gradients. The aircraft $\mathrm{O}_{3}$ data exhibited an "S" shaped vertical profile as seen elsewhere in the tropics, and also in agreement with sonde data collected from launches at Cotonou and $\mathrm{Ni}$ amey. This profile appears to result from significant losses in the LT due to rapid deposition to forested areas and photochemical destruction in the moist monsoon air, and convective uplift of $\mathrm{O}_{3}$-poor air to the UT. The vertical profile of $\mathrm{CO}$, on the other hand, exhibited a "C" shaped profile, which is thought to be due to emissions from the surface and the convective uplift of CO-rich air to the UT. Both of these profiles were disturbed, particularly in the south of the region, by the intrusions in the lower and middle troposphere of air from the southern hemisphere impacted by biomass burning. Comparisons with MOPITT satellite $\mathrm{CO}$ data and $\mathrm{O}_{3}$ vertical profiles from sondes and MOZAIC aircraft show these intrusions to be regular phenomena, but that their impact on West Africa in 2006 was greater than compared to other recent wet seasons.

On the whole $\mathrm{O}_{3}$ and $\mathrm{CO}$ were anticorrelated and this relationship tended to be a function of water vapour, illustrating the stratospheric source of tropospheric ozone and the relatively short photochemical lifetime of ozone in the moist, monsoon layer air into which $\mathrm{CO}$ is emitted. There were a couple of exceptions to this: urban plumes, in particular that of Lagos; the biomass burning plumes. Net-photochemical ozone formation is inferred for these air masses and for some biomass burning plumes production of $\mathrm{O}_{3}$ has been calculated to occur for several days downwind. In addition there is evidence for net ozone formation in convective outflow in the UT with observations indicating uplift of radical precursors coincident with either uplift of NO or an emission of NO from lightning, and in the boundary layer in the north following emission of NO from recently wetted bare soils. This latter effect, along with enhanced deposition to the forested areas contributes to a latitudinal gradient of $\mathrm{O}_{3}$ in the lower troposphere. Biogenic volatile organic compounds are also important in defining the composition both for the boundary layer and upper tropospheric convective outflow.

Mineral dust aerosols were found to be ubiquitous over the entire sampling area. Mobilisation of mineral dust was observed at the leading edges of mesoscale convective system cold-pools and of the monsoon nocturnal flow in the ITD region. Measurements of the vertical distribution and properties illustrate the differences for dust mobilised from different soil types. The frequency and relative abundance of such events, and therefore their impact at the global scale, cannot be assessed by aircraft measurements only but require longterm data series, ground-based and/or spaceborne. The integration of different types of observations will be the priority of future research.

Formation of secondary organic aerosols (SOA) was observed over vegetated soils, yielding the first estimates of SOA across the West African Sahel. Depending on the production yields used, either from data obtained under atmospherically relevant mass concentrations or from chamber studies at higher mass concentrations, measurements may or may not approach the SOA abundance predicted by models. This result points out to the necessity and the challenge of performing chamber experiments at atmospheric conditions in order to reconcile laboratory measurements, field observations, and model predictions.

Particle nucleation in the upper troposphere is observed in the outflow of MCSs after few hours of ageing. Nonetheless, fresh outflow is a rather efficient sink for particles of all sizes. 


\section{Appendix A}

\section{Appendix A - Details of intercomparison of aircraft data}

On 16 August 2006 the D-F20 joined the BAe-146 in formation for a straight and level run westwards at Flight Level (FL) $100(697 \mathrm{hPa})$ for around $15 \mathrm{~min}$ (14:58:1015:12:49 UTC). The two aircraft turned and then made a profile ascent in formation to FL190 (485 hPa) for an eastwards run (15:24:29-15:44:36 UTC). Later the BAe-146 joined the F-F20 at FL190 for a westwards level run (15:51:5116:07:40 UTC) followed by an eastwards run at FL100 (16:20:31-16:43:16 UTC). Finally the BAe-146 met up with the ATR-42 for a level run eastwards at an altitude of $0.94 \mathrm{~km}(906 \mathrm{hPa})(17: 00: 20-17: 16: 01 \mathrm{UTC})$. The level runs were all in clear air but dust layers were observed from FL105 to FL160 and below FL100 to the boundary layer top $(\sim 1.5 \mathrm{~km})$. In all cases the aircraft joining formation held position just behind and on the right hand side of the lead aircraft with a separation of about $30 \mathrm{~m}$.

Regarding the gas phase, the data comparison was performed blind with the data of Table 4 being uploaded simultaneously to an ftp site on 20 Dec 2006. J. Methven, who was not responsible for any of the instruments, calculated the statistics comparing the data. In all cases a running median filter with a window width of $10 \mathrm{~s}$ has been passed through the time series before putting on a common time-base determined by the time-points reported (at $1 \mathrm{~s}$ intervals) by the BAe-146. A running median was used because it does not influence the timing or gradient of step changes in properties between air masses, unlike a running mean which smooths gradients. The filter was applied to avoid the need for interpolation between time-points from different aircraft (filtered data points were allocated to the closest time-point on the common time-base). Moreover, the instrument response times for composition measurements are greater than $1 \mathrm{~s}$. The statistics have also been calculated using the unfiltered $1 \mathrm{~s}$ data and it was found that this reduces differences and their correlations by a very small amount from Table 4 . This implies that there is little variability in the high frequency $(>0.1 \mathrm{~Hz})$ range, even for wind and temperature measurements which are reported at $16 \mathrm{~Hz}$ on the BAe-146.

The comparison of the CO-standards used during AMMA was conducted at DLR by M. Lichtenstern with a commercial CO-analyzer (AL5001) using two NOAA standards as reference (142.4 ppbv and $329.5 \mathrm{ppbv})$ to derive the sensitivity of the instrument to $\mathrm{CO}$ mixing ratio. Each standard was measured twice for a period of $9 \mathrm{~min}$ and the instrument background was checked every 30 min using $\mathrm{CO}$-free air.

Intercomparing aerosol measurements onboard aircraft is challenging. First, due to the spatial variability of the aerosol fields, differences might be observed depending on the aircraft relative position. Second, for instrumentation located in the aircraft cabin, aerosol measurements depend not only on the instrument performances but also on the passing efficiency of the inlet to which the instruments are connected (Wendisch et al., 2002). Wing-mounted open-cavity instruments such as PMS probes (PCASP, FSSP) for measuring the aerosol size distribution are preferred as they are not affected by inlet artefacts (Wendisch et al., 2002). The aerosol measurement intercomparison exercise was only of limited use in this case due to several facts: only the BAe-146 and the D-F20 flew wing-to-wing; some instrumentation failed (e.g. PMS probes onboard the ATR-42, CN counter on the BAe-146); and finally the passing efficiencies are unknown for most of the inlets onboard the three aircraft.

\section{Supplementary material related to this article is available online at: http://www.atmos-chem-phys.net/10/7575/2010/ acp-10-7575-2010-supplement.zip.}

Acknowledgements. Based on a French initiative, AMMA was built by an international scientific group and is currently funded by a large number of agencies, especially from France, the UK, the US and Africa. This work was funded by the EU and by the UK Natural Environment Research Council through the AMMA-UK Consortium grant and the National Centre for Atmospheric Science. The authors are grateful to A. Oulanowski (Central Aerological Observatory, Russian Federation) and F. Ravegnani (Consiglio Nazionale delle Ricerche, Italy) for data from the M55 along with David Stewart (University of East Anglia) for data from the BAe-146. The authors wish to thank everyone involved in the operation of the research aircraft (FAAM, SAFIRE and DLR).

Edited by: F. Dentener

\section{References}

Adon, M., Galy-Lacaux, C., Yobou, V., Delon, C., Lacaux, J. P., Castera, P., Gardrat, E., Pienaar, J., Al Ourabi, H., Laouali, D., Diop, B., Sigha-Nkamdjou, L., Akpo, A., Tathy, J. P., Lavenu, F., and Mougin, E.: Long term measurements of sulfur dioxide, nitrogen dioxide, ammonia, nitric acid and ozone in Africa using passive samplers, Atmos. Chem. Phys. Discuss., 10, 4407-4461, doi:10.5194/acpd-10-4407-2010, 2010.

Aghedo, A. M., Schultz, M. G., and Rast, S.: The influence of African air pollution on regional and global tropospheric ozone, Atmos. Chem. Phys., 7, 1193-1212, doi:10.5194/acp-7-11932007, 2007.

Alfaro, S. C. and Gomes, L.: Modeling mineral aerosol production by wind erosion: Emission intensities and aerosol size distributions in source areas, J. Geophys. Res., 106, 18075-18084, 2001.

Ancellet, G., Leclair de Bellevue, J., Mari, C., Nedelec, P., Kukui, A., Borbon, A., and Perros, P.: Effects of regional-scale and convective transports on tropospheric ozone chemistry revealed by aircraft observations during the wet season of the AMMA campaign, Atmos. Chem. Phys., 9, 383-411, doi:10.5194/acp-9-3832009, 2009.

Andrs-Hernndez, M. D., Kartal, D., Reichert, L., Burrows, J. P., Meyer Arnek, J., Lichtenstern, M., Stock, P., and Schlager, 
H.: Peroxy radical observations over West Africa during AMMA 2006: photochemical activity in the outflow of convective systems, Atmos. Chem. Phys., 9, 3681-3695, doi:10.5194/acp-93681-2009, 2009.

Andrés-Hernández, M. D., Stone, D., Brookes, D. M., Commane, R., Reeves, C. E., Huntrieser, H., Heard, D. E., Monks, P. S., Burrows, J. P., Schlager, H., Kartal, D., Evans, M. J., Floquet, C. F. A., Ingham, T., Methven, J., and Parker, A. E.: Peroxy radical partitioning during the amma radical intercomparison exercise, Atmos. Chem. Phys. Discuss., 10, 8447-8486, doi:10.5194/acpd-10-8447-2010, 2010.

Barret, B., Ricaud, P., Mari, C., Attié, J.-L., Bousserez, N., Josse, B., Le Flochmon, E., Livesey, N. J., Massart, S., Peuch, V.H., Piacentini, A., Sauvage, B., Thouret, V., and Cammas, J.P.: Transport pathways of $\mathrm{CO}$ in the African upper troposphere during the monsoon season: a study based upon the assimilation of spaceborne observations, Atmos. Chem. Phys., 8, 3231-3246, doi:10.5194/acp-8-3231-2008, 2008.

Barret, B., Williams, J. E., Bouarar, I., Yang, X., Josse, B., Law, K., Pham, M., Le Flochmoën, E., Liousse, C., Peuch, V. H., Carver, G. D., Pyle, J. A., Sauvage, B., van Velthoven, P., Schlager, H., Mari, C., and Cammas, J.-P.: Impact of West African Monsoon convective transport and lightning NOx production upon the upper tropospheric composition: a multi-model study, Atmos. Chem. Phys., 10, 5719-5738, doi:10.5194/acp-10-57192010, 2010.

Bechara, J., Borbon, A., Jambert, C., Colomb, A., and Perros, P. E.: Evidence of the impact of deep convection on reactive volatile organic compounds in the upper tropical troposphere during the AMMA experiment in West Africa, Atmos. Chem. Phys. Discuss., 9, 20309-20346, doi:10.5194/acpd-9-20309-2009, 2009.

Bielders, C. L., Vrieling, A., Rajot, J. L., and Skidmore, E.: Onfarm evaluation of field-scale soil losses by wind erosion under traditional management in the sahel, Soil erosion research for the 21st century, proceedings, edited by: Ascough, J. C. and Flanagan, D. C., 494-497, 2001.

Bielders, C. L., Rajot, J. L., and Amadou, M.: Transport of soil and nutrients by wind in bush fallow land and traditionally managed cultivated fields in the sahel, Geoderma, 109, 19-39, 2002.

Bielders, C. L., Rajot, J. L., and Michels, K.: L'érosion éolienne dans le sahel nigérien : Influence des pratiques culturales actuelles et méthodes de lutte, Sécheresse, 15, 19-32, 2004.

Borrmann, S., Kunkel, D., Weigel, R., Minikin, A., Deshler, T., Wilson, J. C., Curtius, J., Volk, C. M., Homan, C. D., Ulanovsky, A., Ravegnani, F., Viciani, S., Shur, G. N., Belyaev, G. V., Law, K. S., and Cairo, F.: Aerosols in the tropical and subtropical UT/LS: in-situ measurements of submicron particle abundance and volatility, Atmos. Chem. Phys., 10, 5573-5592, doi:10.5194/acp-10-5573-2010, 2010.

Bou Karam, D., Flamant, C., Knippertz, P., Reitebuch, O., Pelon, J., Chong, M., and Dabas, A.: Dust emissions over the sahel associated with the west african monsoon inter-tropical discontinuity region: A representative case stuy, Q. J. Roy. Meteorol. Soc., 134, 621-634, 2008.

Bou Karam, D., Flamant, C., Tulet, P., Chaboureau, J. P., Dabas, A., and Todd, M. C.: Estimate of sahelian dust emissions in the intertropical discontinuity region of the west african monsoon, Journal of Geophysical Research-Atmospheres, 114, D13106, doi:10.1029/2008jd011444, 2009.
Brough, N., Reeves, C. E., Penkett, S. A., Stewart, D. J., Dewey, K., Kent, J., Barjat, H., Monks, P. S., Ziereis, H., Stock, P., Huntrieser, H., and Schlager, H.: Intercomparison of aircraft instruments on board the C-130 and Falcon 20 over southern Germany during EXPORT 2000, Atmos. Chem. Phys., 3, 21272138, doi:10.5194/acp-3-2127-2003, 2003.

Bruneau, D., Quaglia, P., Flamant, C., Meissonnier, M., and Pelon, J.: The airborne lidar leandre ii for water-vapor profiling in the troposphere, I. System description, Appl. Opt., 40, 3450-3475, 2001.

Cairo, F., Pommereau, J. P., Law, K. S., Schlager, H., Garnier, A., Fierli, F., Ern, M., Streibel, M., Arabas, S., Borrmann, S., Berthelier, J. J., Blom, C., Christensen, T., D’Amato, F., Di Donfrancesco, G., Deshler, T., Diedhiou, A., Durry, G., Engelsen, O., Goutail, F., Harris, N. R. P., Kerstel, E. R. T., Khaykin, S., Konopka, P., Kylling, A., Larsen, N., Lebel, T., Liu, X., MacKenzie, A. R., Nielsen, J., Oulanowski, A., Parker, D. J., Pelon, J., Polcher, J., Pyle, J. A., Ravegnani, F., Rivire, E. D., Robinson, A. D., Rckmann, T., Schiller, C., Simes, F., Stefanutti, L., Stroh, F., Some, L., Siegmund, P., Sitnikov, N., Vernier, J. P., Volk, C. M., Voigt, C., von Hobe, M., Viciani, S., and Yushkov, V.: An introduction to the SCOUT-AMMA stratospheric aircraft, balloons and sondes campaign in West Africa, August 2006: rationale and roadmap, Atmos. Chem. Phys., 10, 2237-2256, doi:10.5194/acp10-2237-2010, 2010.

Capes, G., Murphy, J. G., Reeves, C. E., McQuaid, J. B., Hamilton, J. F., Hopkins, J. R., Crosier, J., Williams, P. I., and Coe, H.: Secondary organic aerosol from biogenic VOCs over West Africa during AMMA, Atmos. Chem. Phys., 9, 3841-3850, doi:10.5194/acp-9-3841-2009, 2009.

Capes, G., Murphy, J. G., Reeves, C. E., McQuaid, J. B., Hamilton, J. F., Hopkins, J. R., Crosier, J., Williams, P. I., and Coe, H.: Secondary organic aerosol from biogenic VOCs over West Africa during AMMA, Atmos. Chem. Phys., 9, 3841-3850, doi:10.5194/acp-9-3841-2009, 2009.

Chung, S. H. and Seinfeld, J. H.: Global distribution and climate forcing of carbonaceous aerosols, J. Geophys. Res.-Atmos., 107, 4407, doi:10.1029/2001JD001397, 2002.

Claquin, T., Schulz, M., and Balkanski, Y. J.: Modeling the mineralogy of atmospheric dust sources, J. Geophys. Res.-Atmos., 104, 22243-22256, 1999.

Commane, R., Floquet, C. F. A., Ingham, T., Stone, D., Evans, M. J., and Heard, D. E.: Observations of $\mathrm{OH}$ and $\mathrm{HO} 2$ radicals over West Africa, Atmos. Chem. Phys. Discuss., 10, 7265-7322, doi:10.5194/acpd-10-7265-2010, 2010.

Cros, B., Delon, C., Affre, C., Marion, T., Druilhet, A., Perros, P. E., and Lopez, A.: Sources and sinks of ozone in savanna and forest areas during expresso: Airborne turbulent flux measurements, J. Geophys. Res.-Atmos., 105, 29347-29358, 2000.

Crumeyrolle, S., Gomes, L., Tulet, P., Matsuki, A., Schwarzenboeck, A., and Crahan, K.: Increase of the aerosol hygroscopicity by cloud processing in a mesoscale convective system: a case study from the AMMA campaign, Atmos. Chem. Phys., 8, 6907-6924, doi:10.5194/acp-8-6907-2008, 2008.

Crumeyrolle, S., Tulet, P., Garcia-Carreras, L., Flamant, C., Parker, D. J., Matsuki, A., Schwarzenboeck, A., Formenti, P., and Gomes, L.: Transport of dust particles from the Bodl region to the monsoon layer: AMMA case study of the 9-14 June 2006 period, Atmos. Chem. Phys. Discuss., 10, 5051-5090, 
doi:10.5194/acpd-10-5051-2010, 2010

Delon, C., Reeves, C. E., Stewart, D. J., Serca, D., Dupont, R., Mari, C., Chaboureau, J. P., and Tulet, P.: Biogenic nitrogen oxide emissions from soils - impact on nox and ozone over west africa during amma (african monsoon multidisciplinary experiment): Modelling study, Atmos. Chem. Phys., 8, 2351-2363, doi:10.5194/acp-8-2351-2008, 2008.

Denman, K. L., Brasseur, G., Chidthaisong, A., Ciais, P., Cox, P. M., Dickinson, R. E., Hauglustaine, D., Heinze, C., Holland, E., Jacob, D., Lohmann, U., Ramachandran, S., da Silva Dias, P. L., Wofsy, S. C., and Zhang, X.: Couplings Between Changes in the Climate System and Biogeochemistry. In: Climate Change 2007: The Physical Science Basis. Contribution of Working Group I to the Fourth Assessment Report of the Intergovernmental Panel on Climate Change edited by: Solomon, S., Qin, D., Manning, M., Chen, Z., Marquis, M., Averyt, K. B., Tignor, M., and Miller, H. L., Cambridge University Press, Cambridge, UK and New York, NY, USA, 2007.

Echalar, F., Gaudichet, A., Cachier, H., and Artaxo, P.: Aerosol emissions by tropical forest and savanna biomass burning - characteristic trace-elements and fluxes, Geophys. Res. Lett., 22, 3039-3042, 1995.

Emmons, L. K., Edwards, D. P., Deeter, M. N., Gille, J. C., Campos, T., Nedelec, P., Novelli, P., and Sachse, G.: Measurements of pollution in the troposphere (mopitt) validation through 2006, Atmos. Chem. Phys., 9, 1795-1803, doi:10.5194/acp-9-1795-2009, 2009.

Fan, S. M., Horowitz, L. W., Levy II, H., and Moxim, W. J.: Impact of air pollution on wet deposition of mineral dust aerosols, Geophys. Res. Lett., 1, L02104, doi:10.1029/2003GL0118501, 2004.

Fehsenfeld, F. C., Ancellet, G., Bates, T. S., Goldstein, A. H., Hardesty, R. M., Honrath, R., Law, K. S., Lewis, A. C., Leaitch, R., McKeen, S., Meagher, J., Parrish, D. D., Pszenny, A. A. P., Russell, P. B., Schlager, H., Seinfeld, J., Talbot, R., and Zbinden, R.: International consortium for atmospheric research on transport and transformation (icartt): North america to Europe - overview of the 2004 summer field study, J. Geophys. Res.-Atmos., 111, D23S01, doi:10.1029/2006JD007829, 2006.

Ferreira, J., Reeves, C. E., Murphy, J. G., L., G.-C., Parker, D. J., and Oram, D. E.: Isoprene emissions modelling for west africa using megan, Atmos. Chem. Phys. Discuss., 10, 6923-6953, doi:10.5194/acpd-10-6923-2010, 2010.

Fiedler, V., Arnold, F., Ludmann, S., Minikin, A., Pirjola, L., Dornbrack, A., and Schlager, H.: African biomass burning plumes over the atlantic: Aircraft based measurements and implications for $\mathrm{h}_{2} \mathrm{SO}_{4}$ and $\mathrm{hno}_{3}$ mediated smake partical activation, Atmos. Chem. Phys. Discuss., 10, 7699-7743, doi:10.5194/acpd10-7699-2010, 2010.

Fierli, F., Orlandi, E., Law, K. S., Cagnazzo, C., Cairo, F., Borrmann, S., Donfrancesco, G. D., Schiller, C., Ravegnani, F., and Volk, M.: Impact of deep convection in the upper troposphere in west africa: In-situ observations and mesoscale modelling, submitted, Atmos. Chem. Phys. Discuss., 2010.

Flamant, C., Chaboureau, J.-P., Parker, D. J., Taylor, C. M., Cammas, J.-P., Bock, O., Timouck, F., and Pelon, J.: Airborne observations of the impact of a convective system on the planetary boundary layer thermodynamics and aerosol distribution in the inter-tropical discontinuity region of the west african monsoon,,
Quart. J. Roy. Meteorol. Soc., 133, 1175-1189, 2007.

Flamant, C., Knippertz, P., Parker, D., Chaboureau, J.-P., Lavaysse, C., Agusti-Panareda, A., and Kergoat, L.: The impact of a mesoscale convective system cold-pool on the northward propagation of the inter-tropical discontinuity over west africa, Q. J. Roy. Meteorol. Soc., 135, 139-165, 2009a.

Flamant, C., Lavaysse, C., Todd, M., Chaboureau, J.-P., and Pelon, J.: Multi-platform observations of a springtime case of bodélé and sudan dust emission, transport and scavenging over west africa, Q. J. Roy. Meteorol. Soc., 135,, 413-430, 2009b.

Flamant, C., Parker, D., Knippertz, P., Lavaysse, C., and Chaboureau, J.-P.: The impact of african easterly waves on the sahelian planetary boundary layer and convective initiation in the aïr mountains region: An observational case study, Q. J. Roy. Meteorol. Soc., in preparation, 2009c.

Folkins, I., Braun, C., Thompson, A. M., and Witte, J.: Tropical ozone as an indicator of deep convection, J. Geophys. Res.Atmos., 107(D13), 4184, doi:10.1029/2001JD001178, 2002.

Formenti, P., Elbert, W., Maenhaut, W., Haywood, J., and Andreae, M. O.: Chemical composition of mineral dust aerosol during the saharan dust experiment (shade) airborne campaign in the cape verde region, september 2000, J. Geophys. Res.-Atmos., 108, 8576, doi:10.1029/2002jd002648, 2003.

Formenti, P., Grand, N., Chevaillier, S., Schmestig, C., and Desboeufs, K.: Airborne observations of aerosol particles over western africa in the summer monsoon season: Spatial and vertical variability of physico-chemical and optical properties, Atmos. Chem. Phys. Discuss., in preparation, 2010.

Forster, P., Ramaswamy, V., Artaxo, P., Berntsen, T., Betts, R., Fahey, D. W., Haywood, J., Lean, J., Lowe, D. C., Myhre, G., Nganga, J., Prinn, R., Raga, G., Schulz, M., and Van Dorland, R.: Changes in Atmospheric Constituents and in Radiative Forcing. In: Climate Change 2007: The Physical Science Basis, Contribution of Working Group I to the Fourth Assessment Report of the Intergovernmental Panel on Climate Change, edited by: Solomon, S., Qin, D., Manning, M., Chen, Z., Marquis, M., Averyt, K. B., Tignor, M., and Miller, H. L., Cambridge University Press, Cambridge, United Kingdom and New York, NY, USA, 2007.

Garcia-Carreras, L., Parker, D. J., Taylor, C. M., Reeves, C. E., and Murphy, J. G.: Impact of mesoscale vegetation heterogeneities on the dynamical and thermodynamic properties of the planetary boundary layer, J. Geophys. Res., 115, D03102, doi:10.1029/2009JD012811, 2010.

Generoso, S., Breon, F. M., Balkanski, Y., Boucher, O., and Schulz, M.: Improving the seasonal cycle and interannual variations of biomass burning aerosol sources, Atmos. Chem. Phys., 3, 12111222, doi:10.5194/acp-3-1211-2003, 2003.

Generoso, S., Bey, I., Labonne, M., and Breon, F. M.: Aerosol vertical distribution in dust outflow over the atlantic: Comparisons between geos-chem and cloud-aerosol lidar and infrared pathfinder satellite observation (calipso), J. Geophys. Res.-Atmos., 113, D24209, doi:10.1029/2008jd010154, 2008.

Goudie, A. S. a. N. J. M.: The changing frequency of dust storms through time, Clim. Change, 20, 197-225, 1992.

Green, T. J., Reeves, C. E., Fleming, Z. L., Brough, N., Rickard, A. R., Bandy, B. J., Monks, P. S., and Penkett, S. A.: An improved dual channel perca instrument for atmospheric measurements of peroxy radicals, J. Environ. Monit., 8, 530-536, 
10.1039/b514630e, 2006.

Greenberg, J. P., Guenther, A. B., Madronich, S., Baugh, W., Ginoux, P., Druilhet, A., Delmas, R., and Delon, C.: Biogenic volatile organic compound emissions in central africa during the experiment for the regional sources and sinks of oxidants (expresso) biomass burning season, J. Geophys. Res.-Atmos., 104, 30659-30671, 1999.

Greenberg, J. P., Guenther, A., Harley, P., Otter, L., Veenendaal, E. M., Hewitt, C. N., James, A. E., and Owen, S. M.: Eddy flux and leaf-level measurements of biogenic voc emissions from mopane woodland of botswana, J. Geophy. Res.-Atmos., 108, 8466, doi:10.1029/2002JD002317, 2003.

Guenther, A., Hewitt, C. N., Erickson, D., Fall, R., Geron, C., Graedel, T., Harley, P., Klinger, L., Lerdau, M., McKay, W. A., Pierce, T., Scholes, B., Steinbrecher, R., Tallamraju, R., Taylor, J., and Zimmerman, P.: A global-model of natural volatile organic-compound emissions, J. Geophys. Res.-Atmos., 100, 8873-8892, 1995.

Guenther, A., Otter, L., Zimmerman, P., Greenberg, J., Scholes, R., and Scholes, M.: Biogenic hydrocarbon emissions from southern african savannas, J. Geophys. Res.-Atmos., 101, 25859-25865, 1996.

Guenther, A., Baugh, B., Brasseur, G., Greenberg, J., Harley, P., Klinger, L., Serca, D., and Vierling, L.: Isoprene emission estimates and uncertainties for the central african expresso study domain, J. Geophys. Res.-Atmos., 104, 30625-30639, 1999.

Guenther, A., Karl, T., Harley, P., Wiedinmyer, C., Palmer, P. I., and Geron, C.: Estimates of global terrestrial isoprene emissions using megan (model of emissions of gases and aerosols from nature), Atmos. Chem. Phys., 6, 3181-3210, doi:10.5194/acp-63181-2006, 2006.

Hao, W. M., and Liu, M. H.: Spatial and temporal distribution of tropical biomass burning, Global Biogeochem. Cy., 8, 495-503, 1994.

Haywood, J., Francis, P., Osborne, S., Glew, M., Loeb, N., Highwood, E., Tanre, D., Myhre, G., Formenti, P., and Hirst, E.: Radiative properties and direct radiative effect of saharan dust measured by the c-130 aircraft during shade: 1 . Solar spectrum, J. Geophys. Res.-Atmos., 108, 8577, doi:10.1029/2002jd002687, 2003.

Heard, D. E.: Atmospheric field measurements of the hydroxylradical using laser-induced fluorescence spectroscopy, Annual Review of Physical Chemistry, 57, 191-216, 2006.

Homan, C. D., Volk, C. M., Kuhn, A. C., Werner, A., Baehr, J., Viciani, S., Ulanovski, A., and Ravegnani, F.: Tracer measurements in the tropical tropopause layer during the AMMA/SCOUTO3 aircraft campaign, Atmos. Chem. Phys., 10, 3615-3627, doi:10.5194/acp-10-3615-2010, 2010.

Hopkins, J. R., Evans, M. J., Lee, J. D., Lewis, A. C., Marsham, J. H., McQuaid, J. B., Parker, D. J., Stewart, D. J., Reeves, C. E., and Purvis, R. M.: Direct estimates of emissions from the megacity of lagos, Atmos. Chem. Phys., 9, 8471-8477, doi:10.5194/acp-9-8471-2009, 2009.

Jaegle, L., Martin, R. V., Chance, K., Steinberger, L., Kurosu, T. P., Jacob, D. J., Modi, A. I., Yoboue, V., Sigha-Nkamdjou, L., and Galy-Lacaux, C.: Satellite mapping of rain-induced nitric oxide emissions from soils, J. Geophys. Res.-Atmos., 109, 8802, doi:10.1029/2002JD003121, 2004.

Janicot, S., Thorncroft, C. D., Ali, A., Asencio, N., Berry, G., Bock,
O., Bourles, B., Caniaux, G., Chauvin, F., Deme, A., Kergoat, L., Lafore, J.-P., Lavaysse, C., Lebel, T., Marticorena, B., Mounier, F., Nedelec, P., Redelsperger, J.-L., Ravegnani, F., Reeves, C. E., Roca, R., de Rosnay, P., Schlager, H., Sultan, B., Tomasini, M., Ulanovsky, A., and ACMAD forecasters team: Large-scale overview of the summer monsoon over West Africa during the AMMA field experiment in 2006, Ann. Geophys., 26, 25692595, doi:10.5194/angeo-26-2569-2008, 2008.

Jenkins, G. S. and Ryu, J. H.: Linking horizontal and vertical transports of biomass fire emissions to the tropical atlantic ozone paradox during the northern hemisphere winter season: Climatology, Atmos. Chem. Phys., 4, 449-469, doi:10.5194/acp-4-449-2004, 2004a.

Jenkins, G. S. and Ryu, J. H.: Space-borne observations link the tropical atlantic ozone maximum and paradox to lightning, Atmos. Chem. Phys., 4, 361-375, doi:10.5194/acp-4-361-2004, 2004 b.

Kanakidou, M., Seinfeld, J. H., Pandis, S. N., Barnes, I., Dentener, F. J., Facchini, M. C., Van Dingenen, R., Ervens, B., Nenes, A., Nielsen, C. J., Swietlicki, E., Putaud, J. P., Balkanski, Y., Fuzzi, S., Horth, J., Moortgat, G. K., Winterhalter, R., Myhre, C. E. L., Tsigaridis, K., Vignati, E., Stephanou, E. G., and Wilson, J.: Organic aerosol and global climate modelling: a review, Atmos. Chem. Phys., 5, 1053-1123, doi:10.5194/acp-5-1053-2005, 2005

Karyampudi, V. M., Palm, S. P., Reagen, J. A., Fang, H., Grant, W. B., Hoff, R. M., Moulin, C., Pierce, H. F., Torres, O., Browell, E. V., and Melfi, S. H.: Validation of the saharan dust plume conceptual model using lidar, meteosat, and ecmwf data, B. Am. Meteorol. Soc., 80, 1045-1075, 1999.

Kavouras, I. G., Mihalopoulos, N., and Stephanou, E. G.: Formation of atmospheric particles from organic acids produced by forests, Nature, 395, 683-686, 1998.

Khaykin, S., Pommereau, J.-P., Korshunov, L., Yushkov, V., Nielsen, J., Larsen, N., Christensen, T., Garnier, A., Lukyanov, A., and Williams, E.: Hydration of the lower stratosphere by ice crystal geysers over land convective systems, Atmos. Chem. Phys., 9, 2275-2287, doi:10.5194/acp-9-2275-2009, 2009.

Klinger, L. F., Greenberg, J., Guenther, A., Tyndall, G., Zimmerman, P., M'Bangui, M., and Moutsambote, J. M.: Patterns in volatile organic compound e missions along a savanna-rainforest gradient in central africa, J. Geophys. Res.-Atmos., 103, 14431454, 1998.

Kroll, J. H., Ng, N. L., Murphy, S. M., Flagan, R. C., and Seinfeld, J. H.: Secondary organic aerosol formation from isoprene photooxidation, Environ. Sci. Technol., 40, 1869-1877, 2006.

Law, K. S., Fierli, F., Cairo, F., Schlager, H., Borrmann, S., Streibel, M., Real, E., Kunkel, D., Schiller, C., Ravegnani, F., Ulanovsky, A., d'Amato, F., Viciani, S., and Volk, M.: Air mass origins influencing $\mathrm{ttl}$ chemical composition over west africa during 2006 summer monsoon, Atmos. Chem. Phys. Discuss., 10, 15485 15536, doi:10.5194/acpd-10-15485-2010, 2010.

Lebel, T., Parker, D. J., Flamant, C., Bourles, B., Marticorena, B., Mougin, E., Peugeot, C., Diedhiou, A., Haywood, J. M., Ngamini, J. B., Polcher, J., Redelsperger, J.-L., and Thorncroft, C. D.: The amma field campaigns: Multiscale and multidisciplinary observations in the West African region, Q. J. Roy. Meteorol. Soc., 136(S1), 8-33, doi:10.1002/qj.486, 2009.

Legrand, M.: Satellite remote sensing of desert dust over continents, Physical measurements and signatures in remote sensing, vols 1 
and 2, edited by: Guyot, G. and Phulpin, T., 641-645, 1997.

Liu, X. M., Rivire, E. D., Marcal, V., Durry, G., Hamdouni, A., Arteta, J., and Khaykin, S.: Water vapor budget associated to overshoots in the tropical stratosphere: mesoscale modelling study of 4-5 August 2006 during SCOUT-AMMA, Atmos. Chem. Phys. Discuss., 10, 3975-4025, doi:10.5194/acpd10-3975-2010, 2010.

Mari, C. H., Cailley, G., Corre, L., Saunois, M., Attie, J. L., Thouret, V., and Stohl, A.: Tracing biomass burning plumes from the southern hemisphere during the amma 2006 wet season experiment, Atmos. Chem. Phys., 8, 3951-3961, doi:10.5194/acp8-3951-2008, 2008.

Marsham, J. H., Parker, D. J., Grams, C. M., Taylor, C. M., and Haywood, J. M.: Uplift of saharan dust south of the intertropical discontinuity, J. Geophys. Res., 113, D21102, doi:10.1029/2008JD009844, 2008.

Marticorena, B., Chatenet, B., Rajot, J. L., Traoré, S., Coulibaly, M., Diallo, A., Koné, I., Maman, A., N'Diaye, T., and Zakou, A.: Temporal variability of mineral dust concentrations over West Africa: analyses of a pluriannual monitoring from the AMMA Sahelian Dust Transect, Atmos. Chem. Phys. Discuss., 10, 80518101, doi:10.5194/acpd-10-8051-2010, 2010.

Mathon, V., and Laurent, H.: Life cycle of sahelian mesoscale convective cloud systems, Q. J. Roy. Meteorol. Soc., 127, 377-406, 2001.

Matsuki, A., Quennehen, B., Schwarzenboeck, A., Crumeyrolle, S., Venzac, H., Laj, P., and Gomes, L.: Temporal and spatial variations of aerosol physical and chemical properties over west africa: Amma aircraft campaign in summer 2006, Atmos. Chem. Phys. Discuss., 4463-4500, doi:10.5194/acpd-10-44632010, 2010a.

Matsuki, A., Schwarzenboeck, A., Venzac, H., Laj, P., Crumeyrolle, S., and Gomes, L.: Effect of surface reaction on the cloud nucleating properties of mineral dust: Amma aircraft campaign in summer 2006, Atmos. Chem. Phys., 10, 1057-1069, doi:10.5194/acpd-9-1797-2009, $2010 \mathrm{~b}$.

McConnell, C. L., Highwood, E. J., Coe, H., Formenti, P., Anderson, B., Osborne, S., Nava, S., and Chen, G.: Seasonal variations of the physical and optical characteristics of saharan dust: Results from the dust outflow and deposition to the ocean (dodo) experiment, J. Geophys. Res., 113, D14S05, doi:10.1029/2007JD009606, 2008.

Minga, A., V., T., Saunois, M., Delon, C., Serca, D., Mari, C., Sauvage, B., Mariscal, A., Leriche, M., and Cros, B.: What caused extreme ozone concentrations over Cotonou in December 2005?, Atmos. Chem. Phys., 10, 895-907, doi:10.5194/acp-10895-2010, 2010.

Murphy, J. G., Oram, D. E., and Reeves, C. E.: Measurements of volatile organic compounds over West Africa, Atmos. Chem. Phys., 10, 5281-5294, doi:10.5194/acp-10-5281-2010, 2010.

N'Tchayi Mbourou, G., Bertrand, J. J., and Nicholson, S. E.: The diurnal and seasonal cycles of wind-borne dust over africa north of the equator, J. Appl. Meteor., 36, 868-882, 1997.

N'Tchayi Mbourou, G. M., Bertrand, J., Legrand, M., and Baudet, J.: Temporal and spatial variations of the atmospheric dust loading throughout West Africa over the last thirty years, Ann. Geophys., 12, 265-273, doi:10.1007/s00585-994-0265-3, 1994.

Nganga, D., Minga, A., Cros, B., Biona, C. B., Fishman, J., and Grant, W. B.: The vertical distribution of ozone measured at
Brazzaville, congo during trace a, J. Geophys. Res.-Atmos., 101, 24095-24103, 1996.

Osborne, S. R., Johnson, B. T., Haywood, J. M., Baran, A. J., Harrison, M. A. J., and McConnell, C. L.: Physical and optical properties of mineral dust aerosol during the dust and biomass-burning experiment, J. Geophys. Res., 113, D00C03, doi:10.1029/2007JD009551, 2008.

Otter, L., Guenther, A., Wiedinmyer, C., Fleming, G., Harley, P., and Greenberg, J.: Spatial and temporal variations in biogenic volatile organic compound emissions for africa south of the equator, J. Geophys. Res.-Atmos., 108, 8505, doi:10.1029/2002JD002609, 2003.

Otter, L. B., Guenther, A., and Greenberg, J.: Seasonal and spatial variations in biogenic hydrocarbon emissions from southern african savannas and woodlands, Atmos. Environ., 36, 42654275, 2002.

Palazzi, E., Fierli, F., Cairo, F., Cagnazzo, C., Donfrancesco, G. D., Manzini, E., Ravegnani, F., Schiller, C., D’Amato, F., and Volk, C. M.: Diagnostics of the tropical tropopause layer from in-situ observations and ccm data, Atmos. Chem. Phys., 9, 9349-9367, doi:10.5194/acp-9-9349-2009, 2009.

Parker, D. J., Thorncroft, C. D., Burton, R. R., and Diongue-Niang, A.: Analysis of the african easterly jet, using aircraft observations from the jet2000 experiment, Q. J. Roy. Meteorol. Soc., 131, 1461-1482, 2005.

Peyrille, P., Lafore, J. P., and Redelsperger, J. L.: An idealized two-dimensional framework to study the west african monsoon. Part i: Validation and key controlling factors, J. Atmos. Sci., 64, 2765-2782, 2007.

Pfister, G. G., Emmons, L. K., Hess, P. G., Lamarque, J. F., Orlando, J. J., Walters, S., Guenther, A., Palmer, P. I., and Lawrence, P. J.: Contribution of isoprene to chemical budgets: A model tracer study with the ncar ctm mozart-4, J. Geophys. Res.-Atmos., 113, D02204, doi:10.1029/2007JD008797, 2008.

Rajot, J. L.: Wind blown sediment mass budget of sahelian village land units in Niger, Bulletin De La Societe Geologique De France, 172, 523-531, 2001.

Rajot, J. L., Formenti, P., Alfaro, S., Desboeufs, K., Chevaillier, S., Chatenet, B., Gaudichet, A., Journet, E., Marticorena, B., Triquet, S., Maman, A., Mouget, N., and Zakou, A.: Amma dust experiment: An overview of measurements performed during the dry season special observation period (sop0) at the banizoumbou (niger) supersite, Journal of Geophysical ResearchAtmospheres, 113, D00C14, doi:10.1029/2008jd009906, 2008.

Real, E., Orlandi, E., Law, K. S., Fierli, F., Josset, D., Cairo, F., Schlager, H., Borrmann, S., Kunkel, D., Volk, C. M., McQuaid, J. B., Stewart, D. J., Lee, J., Lewis, A. C., Hopkins, J. R., Ravegnani, F., Ulanovski, A., and Liousse, C.: Cross-hemispheric transport of central African biomass burning pollutants: implications for downwind ozone production, Atmos. Chem. Phys., 10, 3027-3046, doi:10.5194/acp-10-3027-2010, 2010.

Redelsperger, J. L., Thorncroft, C. D., Diedhiou, A., Lebel, T., Parker, D. J., and Polcher, J.: African monsoon multidisciplinary analysis - an international research project and field campaign, B. Am. Meteorol. Soc., 87, 1739-1746, doi:10.1175/bams-8712-1739, 2006.

Richter, A., Burrows, J. P., Nuss, H., Granier, C., and Niemeier, U.: Increase in tropospheric nitrogen dioxide over china observed from space, Nature, 437, 129-132, 2005. 
Saunois, M., Reeves, C. E., Mari, C. H., Murphy, J. G., Stewart, D. J., Mills, G. P., Oram, D. E., and Purvis, R. M.: Factors controlling the mdistribution of ozone in the west african lower troposphere during the amma (african monsoon multidisciplinary analysis) wet season campaign, Atmos. Chem. Phys., 9, 61356155, doi:10.5194/acp-9-6135-2009, 2009.

Sauvage, B., Thouret, V., Cammas, J. P., Gheusi, F., Athier, G., and Nedelec, P.: Tropospheric ozone over equatorial africa: Regional aspects from the mozaic data, Atmos. Chem. Phys., 5, 311-335, doi:10.5194/acp-5-311-2005, 2005.

Sauvage, B., Gheusi, F., Thouret, V., Cammas, J.-P., Duron, J., Escobar, J., Mari, C., Mascart, P., and Pont, V.: Medium-range midtropospheric transport of ozone and precursors over Africa: two numerical case studies in dry and wet seasons, Atmos. Chem. Phys., 7, 5357-5370, doi:10.5194/acp-7-5357-2007, 2007.

Saxton, J. E., Lewis, A. C., Kettlewell, J. H., Ozel, M. Z., Gogus, F., Boni, Y., Korogone, S. O. U., and Serça, D.: Isoprene and monoterpene measurements in a secondary forest in northern Benin, Atmos. Chem. Phys., 7, 4095-4106, doi:10.5194/acp-74095-2007, 2007.

Schiller, C., Grooß, J.-U., Konopka, P., Plöger, F., Santos, F. H. S. d., and Spelten, N.: Hydration and dehydration at the tropical tropopause, Atmos. Chem. Phys., 9, 9647-9660, doi:10.5194/acp-9-9647-2009, 2009.

Schumann, U. and Huntrieser, H.: The global lightning-induced nitrogen oxides source, Atmos. Chem. Phys., 7, 3823-3907, doi:10.5194/acp-7-3823-2007, 2007.

Serca, D., Guenther, A., Klinger, L., Vierling, L., Harley, P., Druilhet, A., Greenberg, J., Baker, B., Baugh, W., Bouka-Biona, C., and Loemba-Ndembi, J.: Expresso flux measurements at upland and lowland congo tropical forest site, Tellus B-Chem. Phys. Meteorol., 53, 220-234, 2001.

Shilling, J. E., Chen, Q., King, S. M., Rosenoern, T., Kroll, J. H., Worsnop, D. R., McKinney, K. A., and Martin, S. T.: Particle mass yield in secondary organic aerosol formed by the dark ozonolysis of alpha-pinene, Atmos. Chem. Phys., 8, 2073-2088, doi:10.5194/acp-8-2073-2008, 2008.

Shim, C., Wang, Y. H., Choi, Y., Palmer, P. I., Abbot, D. S., and Chance, K.: Constraining global isoprene emissions with global ozone monitoring experiment (gome) formaldehyde column measurements, J. Geophys. Res.-Atmos., 110, 2005.

Stewart, D. J., Taylor, C. M., Reeves, C. E., and McQuaid, J. B.: Biogenic nitrogen oxide emissions from soils: impact on NOx and ozone over west Africa during AMMA (African Monsoon Multidisciplinary Analysis): observational study, Atmos. Chem. Phys., 8, 2285-2297, doi:10.5194/acp-8-2285-2008, 2008.

Stone, D., Evans, M. J., Commane, R., Ingham, T., Floquet, C. F. A., McQuaid, J. B., Brookes, D. M., Monks, P. S., Purvis, R., Hamilton, J., Hopkins, J., Lee, J., Lewis, A. C., Stewart, D., Murphy, J., Mills, G., Oram, D., Reeves, C. E., and Heard, D. E.: HOx observations over West Africa during AMMA: impact of isoprene and NOx, Atmos. Chem. Phys. Discuss., 10, 1702917072, doi:10.5194/acpd-10-17029-2010, 2010.

Taylor, C. M., Parker, D. J., and Harris, P. P.: An observational case study of mesoscale atmospheric circulations induced by soil moisture, Geophys. Res. Lett., 34, L15801, doi:10.1029/2007GL030572, 2007.

Tegen, I., and Fung, I.: Contribution to the atmospheric mineral aerosol load from land-surface modification, Journal of Geo- physical Research-Atmospheres, 100, 18707-18726, 1995.

Textor, C., Schulz, M., Guibert, S., Kinne, S., Balkanski, Y., Bauer, S., Berntsen, T., Berglen, T., Boucher, O., Chin, M., Dentener, F., Diehl, T., Easter, R., Feichter, H., Fillmore, D., Ghan, S., Ginoux, P., Gong, S., Kristjansson, J. E., Krol, M., Lauer, A., Lamarque, J. F., Liu, X., Montanaro, V., Myhre, G., Penner, J., Pitari, G., Reddy, S., Seland, O., Stier, P., Takemura, T., and Tie, X.: Analysis and quantification of the diversities of aerosol life cycles within aerocom, Atmos. Chem. Phys., 6, 1777-1813, doi:10.5194/acp-6-1777-2006, 2006.

Textor, C., Schulz, M., Guibert, S., Kinne, S., Balkanski, Y., Bauer, S., Berntsen, T., Berglen, T., Boucher, O., Chin, M., Dentener, F., Diehl, T., Feichter, J., Fillmore, D., Ginoux, P., Gong, S., Grini, A., Hendricks, J., Horowitz, L., Huang, P., Isaksen, I. S. A., Iversen, T., Kloster, S., Koch, D., Kirkevag, A., Kristjansson, J. E., Krol, M., Lauer, A., Lamarque, J. F., Liu, X., Montanaro, V., Myhre, G., Penner, J. E., Pitari, G., Reddy, M. S., Seland, O., Stier, P., Takemura, T., and Tie, X.: The effect of harmonized emissions on aerosol properties in global models - an aerocom experiment, Atmos. Chem. Phys., 7, 4489-4501, doi:10.5194/acp-7-4489-2007, 2007.

Thompson, A. M., Pickering, K. E., McNamara, D. P., Schoeberl, M. R., Hudson, R. D., Kim, J. H., Browell, E. V., Kirchhoff, V., and Nganga, D.: Where did tropospheric ozone over southern africa and the tropical atlantic come from in october 1992? Insights from toms, gte trace a, and safari 1992, J. Geophys. Res.Atmos., 101, 24251-24278, 1996.

Thorncroft, C. D. and Blackburn, M.: Maintenance of the african easterly jet, Qu. J. Roy. Meteorol. Soc., 125, 763-786, 1999.

Thorncroft, C. D., Parker, D. J., Burton, R. R., Diop, M., Ayers, J. H., Barjat, H., Devereau, S., Diongue, A., Dumelow, R., Kindred, D. R., Price, N. M., Saloum, M., Tayor, C. M., and Tompkins, A. M.: The jet 2000 project - aircraft observations of the african easterly jet and african easterly waves, B. Am. Meteorol. Soc., 84, 337-351, 2003.

Thouret, V., Saunois, M., Minga, A., Mariscal, A., Sauvage, B., Solete, A., Agbangla, D., Nedelec, P., Mari, C., Reeves, C. E., and Schlager, H.: An overview of two years of ozone radio soundings over cotonou as part of amma, Atmos. Chem. Phys., 9, 61576174, doi:10.5194/acp-9-6157-2009, 2009.

van Aardenne, J. A., Dentener, F. J., Olivier, J. G. J., Goldewijk, C., and Lelieveld, J.: A 1 degrees $\times 1$ degrees resolution data set of historical anthropogenic trace gas emissions for the period 1890-1990, Global Biogeoch. Cy., 15, 909-928, 2001.

Voigt, C., Schlager, H., Roiger, A., Stenke, A., Reus, M. d., Borrmann, S., Jensen, E., Schiller, C., Konopka, P., and Sitnikov, N.: Detection of reactive nitrogen containing particles in the tropopause region - evidence for a tropical nitric acid trihydrate (nat) belt, Atmos. Chem. Phys., 8, 7421-7430, doi:10.5194/acp8-7421-2008, 2008.

Volkamer, R., Jimenez, J. L., San Martini, F., Dzepina, K., Zhang, Q., Salcedo, D., Molina, L. T., Worsnop, D. R., and Molina, M. J.: Secondary organic aerosol formation from anthropogenic air pollution: Rapid and higher than expected, Geophys. Res. Lett., 33, 2006.

Weller, R., Lilischkis, R., Schrems, O., Neuber, R., and Wessel, S.: Vertical ozone distribution in the marine atmosphere over the central atlantic ocean (56 degrees S 50 degrees N), J. Geophys. Res.-Atmos., 101, 1387-1399, 1996. 
Wendisch, M., Keil, A., Muller, D., Wandinger, U., Wendling, P., Stifter, A., Petzold, A., Fiebig, M., Wiegner, M., Freudenthaler, V., Armbruster, W., von Hoyningen-Huene, W., and Leiterer, U.: Aerosol-radiation interaction in the cloudless atmosphere during lace $98-1$. Measured and calculated broadband solar and spectral surface insolations, J. Geophys. Res.-Atmos., 107, 8124, doi:10.1029/2000jd000226, 2002.

Williams, J. E., Scheele, M. P., van Velthoven, P. F. J., Cammas, J. P., Thouret, V., Galy-Lacaux, C., and Volz-Thomas, A.: The influence of biogenic emissions from africa on tropical tropospheric ozone during 2006: A global modeling study, Atmos. Chem. Phys., 9, 5729-5749, doi:10.5194/acp-9-5729-2009, 2009.

Williams, J. E., Scheele, M. P., van Velthoven, P. F. J., Thouret, V., Saunois, M., Reeves, C. E., and Cammas, J.-P.: The influence of biomass burning on tropospheric composition over the tropical Atlantic Ocean and Equatorial Africa during the West African monsoon in 2006, Atmos. Chem. Phys. Discuss., 10, 7507-7552, doi:10.5194/acpd-10-7507-2010, 2010.
Wittrock, F., Richter, A., Oetjen, H., Burrows, J. P., Kanakidou, M., Myriokefalitakis, S., Volkamer, R., Beirle, S., Platt, U., and Wagner, T.: Simultaneous global observations of glyoxal and formaldehyde from space, Geophys. Res. Lett., 33, 2006.

Yoshioka, M., Mahowald, N., Dufresne, J.-L., and Luo, C.: Simulation of absorbing aerosol indices for african dust, J. Geophys. Res., 110, D18S17, doi:10.1029/2004JD005276, 2005.

Zhang, Q., Jimenez, J. L., Canagaratna, M. R., Allan, J. D., Coe, H., Ulbrich, I., Alfarra, M. R., Takami, A., Middlebrook, A. M., Sun, Y. L., Dzepina, K., Dunlea, E., Docherty, K., DeCarlo, P. F., Salcedo, D., Onasch, T., Jayne, J. T., Miyoshi, T., Shimono, A., Hatakeyama, S., Takegawa, N., Kondo, Y., Schneider, J., Drewnick, F., Borrmann, S., Weimer, S., Demerjian, K., Williams, P., Bower, K., Bahreini, R., Cottrell, L., Griffin, R. J., Rautiainen, J., Sun, J. Y., Zhang, Y. M., and Worsnop, D. R.: Ubiquity and dominance of oxygenated species in organic aerosols in anthropogenically-influenced northern hemisphere midlatitudes, Geophys. Res. Lett., 34, L13801, doi:10.1029/2007GL029979, 2007. 